\title{
Gabapentin and pregabalin for the treatment of neuropathic pain: A review of laboratory and clinical evidence
}

\author{
Ian Gilron MD MSc FRCPC ${ }^{1}$, Sarah JL Flatters BSc PhD²
}

\begin{abstract}
I Gilron, SJL Flatters. Gabapentin and pregabalin for the treatment of neuropathic pain: A review of laboratory and clinical evidence. Pain Res Manage 2006;11( Suppl A):16A-29A.
\end{abstract}

Gabapentin (Neurontin, Pfizer Canada Inc) and pregabalin (Lyrica, Pfizer Canada Inc) were initially developed as antiepileptic drugs and were later discovered to be effective in the treatment of neuropathic pain, creating a relatively novel class of analgesic drugs. The present article reviews the laboratory data on the antinociceptive effects of these drugs in animal models of neuropathic pain, and the clinical trial data on their effects in patients with various neuropathic pain syndromes. Laboratory evidence suggests that both gabapentin and pregabalin can inhibit hyperalgesia and allodynia evoked by a variety of neural insults, including peripheral trauma, diabetes and chemotherapy. Current opinion suggests these antinociceptive effects occur because of drug interaction with the $\alpha_{2} \delta$ subunit of voltage-gated calcium channels. The majority of clinical evidence supports analgesic efficacy in diabetic neuropathy and postherpetic neuralgia, and limited evidence suggests that this efficacy extends to other, but not necessarily all, neuropathic pain syndromes. Early comparative trials and pooled estimates from meta-analyses suggest that analgesic efficacy of gabapentin and pregabalin is perhaps slightly lower than that of tricyclic antidepressants or opioids. However, the most attractive aspects of these two drugs include their tolerability, lack of serious toxicity and ease of use. Future research efforts are warranted to fully understand the mechanism of action of these drugs, to clearly characterize the safety and efficacy of gabapentin and pregabalin in all clinical neuropathic pain syndromes, and to further explore the role of these drugs in the rational polypharmacy of neuropathic pain.

Key Words: Animal pain models; Diabetic neuropathy; Gabapentin; Neuropathic pain; Pain measurement; Postherpetic neuralgia; Pregabalin; Randomized controlled trials

\section{La place de la gabapentine et de la prégabaline dans le traitement de la douleur neuropathique : revue de données cliniques et de données expérimentales}

\begin{abstract}
La gabapentine (Neurontin, Pfizer Canada) et la prégabaline (Lyrica, Pfizer Canada) étaient au départ des antiépileptiques, et ce n'est que plus tard qu'on a découvert leur efficacité dans le traitement de la douleur neuropathique, jusqu'à créer une classe relativement nouvelle d'analgésiques. Le présent article passe en revue des données expérimentales sur les effets antinociceptifs de ces médicaments dans des modèles animaux de la douleur neuropathique ainsi que des données cliniques sur les effets de ces médicaments chez des patients souffrant de différents syndromes douloureux neuropathiques. D'après les données expérimentales, la gabapentine et la prégabaline neutraliseraient l'hyperalgie et l'allodynie provoquées par diverses agressions neuronales, notamment les traumatismes périphériques, le diabète et la chimiothérapie. On croit aujourd'hui que ces effets antinociceptifs résulteraient de l'interaction de ces médicaments avec la sous-unité $\alpha_{2} \delta$ des canaux calciques dépendants des potentiels d'action. Les données cliniques, de leur côté, étayent en grande partie l'efficacité analgésique de ces médicaments dans les cas de neuropathie diabétique ou de névralgie post-zostérienne, mais seul un nombre limité d'entre elles étendraient cette efficacité à d'autres syndromes douloureux neuropathiques, mais encore pas nécessairement à tous. D'après les résultats des premiers essais comparatifs et des estimations groupées de méta-analyses, la gabapentine et la prégabaline auraient une efficacité analgésique légèrement plus faible que les antidépresseurs tricycliques et les opiö̈des, mais elles ont comme grands avantages la tolérabilité, une faible toxicité et une utilisation facile. De nouvelles recherches s'imposent donc pour nous permettre de bien comprendre le mécanisme d'action de ces médicaments, de caractériser clairement l'innocuité et l'efficacité de la gabapentine et de la prégabaline dans tous les syndromes douloureux neuropathiques cliniques et d'examiner davantage la place de ces deux médicaments dans une polypharmacie rationnelle de la douleur neuropathique.
\end{abstract}

analogue, synthesized approximately one decade after gabapentin (10), and has similar pharmacological actions and analgesic effects as gabapentin (1). The purpose of the current review is to present laboratory and clinical evidence supporting the use of gabapentin and pregabalin for the treatment of neuropathic pain. In February 2006, a PubMed search of articles written in English containing the words 'gabapentin' and 'pain' generated 582 citations. Thus, it is not possible to review every published article that has used these agents in this area of research. For this reason, we will state our emphasis in the sections below.
Jabapentin, 1 -(aminomethyl)cyclohexaneacetic acid, of gamma-aminobutyric acid (GABA) synthesized in 1977 (1) and was first developed clinically as an anticonvulsant in the late 1980s (2). The laboratory evaluation of gabapentin as an analgesic was driven by the initial clinical case reports of analgesic effects in neuropathic pain (3-5). This resulted in both laboratory $(6,7)$ and clinical $(8,9)$ assessment of the analgesic efficacy of gabapentin occurring in parallel. Pregabalin, (S)-(+)-3-(aminomethyl)-5-methylhexanoic acid, (Lyrica, Pfizer Canada Inc) is another alkylated GABA
${ }^{1}$ Clinical Pain Research, Departments of Anesthesiology and Pharmacology 89 Toxicology, Queen's University, Kingston, Ontario; ${ }^{2}$ Pain Research Center, Department of Anesthesiology, Perioperative and Pain Medicine, Brigham and Women's Hospital, Harvard Medical School, Boston, Massachusetts, USA

Correspondence: Dr Ian Gilron, Clinical Pain Research Departments of Anesthesiology and Pharmacology Ë Toxicology, Queen's University,

76 Stuart Street, Kingston, Ontario K7L 2V7. Fax 613-548-1375, e-mail gilroni@post.queensu.ca 


\section{LABORATORY EVIDENCE OF ANALGESIC EFFICACY IN MODELS OF NEUROPATHIC PAIN}

Neuropathic pain in humans and animals produces a variety of symptoms, or behavioural signs, such as mechanical allodynia, mechanical hyperalgesia, heat hyperalgesia, cold allodynia and spontaneous pain $(11,12)$. In the present section, we summarize the studies that have evaluated the analgesic efficacy of gabapentin and pregabalin on such behavioural signs in different animal models of neuropathic pain. We reviewed gabapentin and pregabalin studies that used animal models that are most relevant to the clinical setting, ie, models of traumatic nerve injury (chronic constriction injury [CCI], spinal nerve ligation [SNL], partial sciatic ligation [PSL] and spared nerve injury), trigeminal neuralgia, spinal cord injury (SCI), acute herpetic pain, postherpetic neuralgia (PHN), diabetic and chemotherapy-induced neuropathies. We have not included studies that examined the effect of these drugs on acute nociception, formalin-induced pain or in models of inflammatory pain. Gabapentin is now so widely accepted as a treatment for neuropathic pain that it is often used as a comparison or even a positive control in the appraisal of potential novel analgesic therapies in laboratory studies. Consequently, this has markedly enhanced the literature in this area and thus, for the purposes of the present review, we have excluded many of the studies that have used gabapentin as a comparative analgesic standard.

Table 1 summarizes the efficacy of gabapentin in animal models of neuropathic pain and aims to address three questions. First, does gabapentin have differential effects on the different pain behaviours of neuropathic pain? Additionally, how does the dosage of gabapentin or the route of administration influence the antinociceptive effect elicited? This first question was examined by the first study of gabapentin in an animal model (CCI) of neuropathic pain (6). Both intraperitoneal (IP) and intrathecal administration of gabapentin produced the same effects on pain behaviour in CCI rats. Gabapentin partially suppressed mechanical allodynia and completely reversed heat hyperalgesia, but had no effect on mechanical hyperalgesia or spontaneous pain (6). To compare the effect of gabapentin on the assorted pain behaviours of neuropathic pain from multiple studies, we have chosen to examine the studies that employed models of peripheral traumatic nerve injury (ie, CCI, SNL, PSL and spared nerve injury). This group was chosen because it is somewhat homogenous (all involving a peripheral nerve trauma) and the effect of gabapentin has been tested on most of the neuropathic pain pain behaviours (ie, mechanical hyperalgesia, mechanical allodynia, heat hyperalgesia and cold allodynia). To simplify the comparison, only studies that used a single dose, systemic (intravenous, subcutaneous, peroral [PO] or IP) administration of gabapentin in rats were compared. Two studies $(13,14)$ reported gabapentin to be ineffective at inhibiting mechanical hyperalgesia, and in another (15), a partial reversal was seen. Only one of four studies reported a substantial (75\%) reversal of mechanical hyperalgesia following systemic gabapentin (16). In comparison, all eight studies that measured mechanical allodynia found an inhibition of this pain behaviour following systemic gabapentin, although the magnitude of reversal was variable. One-half of these studies reported a partial $(50 \%$ or less) reversal $(6,17-19)$, whereas the other one-half reported a $80 \%$ to $100 \%$ reversal of mechanical allodynia by gabapentin $(13,14,20,21)$. Two studies have examined systemic gabapentin on nerve injury-evoked heat hyperalgesia
$(6,19)$, one reporting a partial $(31 \%)$ reversal (19) and the other a complete reversal of this pain behaviour (6). The effects of systemic gabapentin on cold allodynia are similarly contrasting, with two reports of dose-related inhibition $(16,17)$ and another of inefficacy (14). It should be noted that all of these differential effects of systemic gabapentin on neuropathic pain behaviours cannot be explained by differences in dosage administered, because very similar dose ranges were employed in these studies (Table 1). Therefore, it can be concluded that gabapentin can inhibit all neuropathic pain behaviours induced by peripheral nerve injury. However, given the lack of efficacy demonstrated in several studies by different laboratories, gabapentin's ability to inhibit neuropathic pain cannot be assumed and a complete reversal of these pain behaviours is also not guaranteed. Thus, it is questionable as to whether it is appropriate to use gabapentin as an 'analgesic standard' in laboratory studies of neuropathic pain models.

The dosage of gabapentin does influence the antinociceptive effect evoked, as demonstrated by the many studies showing dose-related effects of gabapentin on all neuropathic pain behaviours (Table 1). However a particular dose of gabapentin given by the same route, in the same model, will not necessarily produce the same effect on pain behaviours across all studies. In the SNL model, for example, IP $100 \mathrm{mg} / \mathrm{kg}$ gabapentin elicited a $51 \%$ reversal of the mechanical withdrawal threshold (17), whereas others found a complete reversal of the mechanical withdrawal threshold to the preinjury baseline responses following IP $100 \mathrm{mg} / \mathrm{kg}$ gabapentin (21). Similarly, in the CCI model, IP $50 \mathrm{mg} / \mathrm{kg}$ gabapentin produced a $31 \%$ reversal of the injuryevoked heat hyperalgesia (19), whereas IP $25 \mathrm{mg} / \mathrm{kg}$ gabapentin was also found to elicit a complete reversal of this pain behaviour (6). It is also noteworthy that although a single dose of gabapentin may have no effect on the pain behaviour in question, repeated administration at the same or lower dose can prove to be effective. This has been demonstrated in the PSL model with $100 \mathrm{mg} / \mathrm{kg} \mathrm{PO}$ (13), in chemotherapy-induced neuropathy models with $100 \mathrm{mg} / \mathrm{kg}$ IP (22) and in an SCI model at repeated lower doses of $30 \mathrm{mg} / \mathrm{kg}$ IP (23). The route of administration is also important in terms of the effect of gabapentin on nociceptive behaviours. Both systemic (intravenous, PO, IP and subcutaneous) and spinal (intrathecal) administration of gabapentin appear to yield similar effects on pain behaviours in models of traumatic nerve injury (6), diabetic neuropathy (24) and PHN (25). In contrast, intraplantar, intracerebroventricular and intracisternal administration of gabapentin have been shown to be ineffective in reducing neuropathic pain behaviours induced by streptozocin (24) and herpes zoster (26).

In marked contrast to the gabapentin literature, we know of only five studies that have assessed the behavioural effects of pregabalin in animal models of neuropathic pain. Oral pregabalin $(30 \mathrm{mg} / \mathrm{kg})$ produced a complete reversal of both static and dynamic mechanical allodynia induced by CCI (27), SNL (27) and streptozocin (24). Systemic pregabalin produced a significant inhibition of mechanical allodynia and heat hyperalgesia caused by sciatic nerve injury $(28,29)$. Pregabalin also evoked a substantial $(70 \%)$ reversal of vincristine-induced mechanical hyperalgesia (30).

\section{MECHANISM OF ACTION}

The analgesic efficacy of gabapentin was established in the mid-1990s, yet more than one decade later there is still debate as to the exact mechanism of action of this drug's analgesic 
TABLE 1 COPYRIGHT PULSUS GROUP INC, D DO NOT COPY

An overview of the effects of gabapentin on the neuropathic pain behaviours in animal models

\begin{tabular}{|c|c|c|c|c|c|}
\hline Model & Dose & Route & Pain behaviour & Maximal effect observed & Reference \\
\hline$\overline{\mathrm{CCl}}$ & $75 \mathrm{mg} / \mathrm{kg}$ & IP & Spontaneous pain & No effect & 6 \\
\hline $\mathrm{CCl}$ & $50 \mathrm{mg} / \mathrm{kg}$ and $100 \mathrm{mg} / \mathrm{kg}$ & IP & Mechanical AD & $35 \%$ reversal & 19 \\
\hline $\mathrm{CCl}$ & $10 \mathrm{mg} / \mathrm{kg}$ to $75 \mathrm{mg} / \mathrm{kg}$ & IP & Mechanical AD & Partial reversal & 6 \\
\hline $\mathrm{CCl}$ & $150 \mu \mathrm{g} / \mathrm{kg}$ & IT & Mechanical AD & Partial reversal & 6 \\
\hline $\mathrm{CCl}$ & $100 \mathrm{mg} / \mathrm{kg}$ & IP & Mechanical HA & $75 \%$ reversal & 16 \\
\hline $\mathrm{CCl}$ & $150 \mu \mathrm{g} / \mathrm{kg}$ & IT & Mechanical HA (pinprick) & No effect & 6 \\
\hline $\mathrm{CCl}$ & $50 \mathrm{mg} / \mathrm{kg}$ and $100 \mathrm{mg} / \mathrm{kg}$ & IP & Heat HA & $31 \%$ reversal & 19 \\
\hline $\mathrm{CCl}$ & $10 \mathrm{mg} / \mathrm{kg}$ to $75 \mathrm{mg} / \mathrm{kg}$ & IP & Heat HA & Dose-related reversal, complete reversal at top dose & 6 \\
\hline $\mathrm{CCl}$ & $15 \mu \mathrm{g} / \mathrm{kg}$ to $75 \mu \mathrm{g} / \mathrm{kg}$ & IT & Heat HA & Dose-related reversal, complete reversal at top dose & 6 \\
\hline $\mathrm{CCl}$ & $150 \mu \mathrm{g} / \mathrm{kg}$ & IT & Heat HA & $80 \%$ reversal & 6 \\
\hline $\mathrm{CCl}$ & $100 \mathrm{mg} / \mathrm{kg}$ and $300 \mathrm{mg} / \mathrm{kg}$ & IP & Cold AD & Dose-related increase in PWL & 17 \\
\hline $\mathrm{CCl}$ & $3 \mathrm{mg} / \mathrm{kg}$ to $30 \mathrm{mg} / \mathrm{kg}$ & IP & Cold AD & Dose-related reversal & 16 \\
\hline SNL (L5+L6) & $100 \mathrm{mg} / \mathrm{kg}$ and $300 \mathrm{mg} / \mathrm{kg}$ & IP & Mechanical AD & $51 \%$ reversal & 17 \\
\hline SNL (L5+L6) & $50 \mathrm{mg} / \mathrm{kg}$ & IP & Mechanical AD & $45 \%$ reversal & 18 \\
\hline SNL (L5+L6) & $10 \mathrm{mg} / \mathrm{kg}$ to $1000 \mathrm{mg} / \mathrm{kg}$ & IT & Mechanical AD & Dose-related reversal & 7 \\
\hline SNL (L5+L6) & $10 \mathrm{mg} / \mathrm{kg}$ to $100 \mathrm{mg} / \mathrm{kg}$ & IP & Mechanical AD & Dose-related reversal, complete reversal at top dose & 21 \\
\hline SNL (L5) & $30 \mathrm{mg} / \mathrm{kg}$ and $90 \mathrm{mg} / \mathrm{kg}$ & SC & Mechanical HA & $30 \%$ to $50 \%$ reversal & 15 \\
\hline SNL (L5+L6) & $100 \mu \mathrm{g} / \mathrm{kg}$ and $300 \mu \mathrm{g} / \mathrm{kg}$ & IT & Mechanical HA & $79 \%$ reversal & 119 \\
\hline SNL (L5+L6) & $100 \mu \mathrm{g} / \mathrm{kg}$ and $300 \mu \mathrm{g} / \mathrm{kg}$ & IT & Heat HA & $74 \%$ reversal & 119 \\
\hline PSL & $30 \mathrm{mg} / \mathrm{kg}$ to $90 \mathrm{mg} / \mathrm{kg}$ & IV & Mechanical AD & Dose-related reversal, complete reversal at top dose & 20 \\
\hline PSL & $100 \mathrm{mg} / \mathrm{kg}$ & $\mathrm{PO}$ & Mechanical AD & $80 \%$ reversal & 13 \\
\hline PSL & $100 \mu \mathrm{g} / \mathrm{kg}$ and $300 \mu \mathrm{g} / \mathrm{kg}$ & IT & Mechanical HA & $30 \%$ reversal & 35 \\
\hline PSL & Rep $100 \mathrm{mg} / \mathrm{kg}$ and $250 \mathrm{mg} / \mathrm{kg}$ & SC & Mechanical HA & $50 \%$ reversal & 35 \\
\hline PSL & $10 \mathrm{mg} / \mathrm{kg}$ to $100 \mathrm{mg} / \mathrm{kg}$ & $\mathrm{PO}$ & Mechanical HA & No effect & 13 \\
\hline PSL (G-P) & $3 \mathrm{mg} / \mathrm{kg}$ to $100 \mathrm{mg} / \mathrm{kg}$ & $\mathrm{PO}$ & Mechanical HA & No effect & 13 \\
\hline PSL (G-P) & Rep $30 \mathrm{mg} / \mathrm{kg}$ and $100 \mathrm{mg} / \mathrm{kg}$ & $\mathrm{PO}$ & Mechanical HA & $90 \%$ reversal & 13 \\
\hline SNI & $100 \mathrm{mg} / \mathrm{kg}$ & IP & Mechanical AD & Complete reversal & 14 \\
\hline SNI & $30 \mathrm{mg} / \mathrm{kg}$ and $100 \mathrm{mg} / \mathrm{kg}$ & IP & Mechanical HA/cold AD & No effect & 14 \\
\hline $\mathrm{CCl}-\mathrm{ION} / \mathrm{TN}$ & Rep $30 \mathrm{mg} / \mathrm{kg}$ and $50 \mathrm{mg} / \mathrm{kg}$ & IP & Mechanical AD & Partial reversal & 120 \\
\hline Tibial nerve injury & $50 \mathrm{mg} / \mathrm{kg}$ and $100 \mathrm{mg} / \mathrm{kg}$ & IP & Mechanical AD & No effect & 121 \\
\hline Brachial plexus avulsion & $70 \mathrm{mg} / \mathrm{kg}$ & $\mathrm{PO}$ & Mechanical HA/cold AD & $80 \%$ reversal & 122 \\
\hline $\begin{array}{l}\text { Superior caudal trunk } \\
\text { transection }\end{array}$ & $30 \mathrm{mg} / \mathrm{kg}$ to $300 \mathrm{mg} / \mathrm{kg}$ & IP & $\begin{array}{l}\text { Mechanical/warm/cold } \\
\text { AD }\end{array}$ & $\begin{array}{l}\text { Dose-related reversal, complete } \\
\text { reversal at top dose }\end{array}$ & 123 \\
\hline $\mathrm{SCl}$ & $10 \mathrm{mg} / \mathrm{kg}$ and $30 \mathrm{mg} / \mathrm{kg}$ & IP & Mechanical AD & Partial reversal & 124 \\
\hline $\mathrm{SCl}$ & $100 \mathrm{mg} / \mathrm{kg}$ & IP & Mechanical AD & Complete reversal & 23 \\
\hline $\mathrm{SCl}$ & Rep 30 mg/kg & IP & Mechanical AD & Complete reversal by third injection & 23 \\
\hline $\mathrm{SCl}$ & $10 \mathrm{mg} / \mathrm{kg}$ and $30 \mathrm{mg} / \mathrm{kg}$ & IP & Heat HA & Complete reversal & 124 \\
\hline $\mathrm{SCl}$ & $100 \mathrm{mg} / \mathrm{kg}$ & IP & Cold AD & $50 \%$ reversal & 23 \\
\hline Diabetic & $10 \mathrm{mg} / \mathrm{kg}$ to $100 \mathrm{mg} / \mathrm{kg}$ & $\mathrm{PO}$ & Mechanical AD & Dose-related reversal, complete reversal at top dose & 24 \\
\hline Diabetic & $1 \mu \mathrm{g} / \mathrm{kg}$ to $100 \mu \mathrm{g} / \mathrm{kg}$ & IT & Mechanical AD & Dose-related reversal, complete reversal at top dose & 24 \\
\hline Diabetic & $30 \mathrm{mg} / \mathrm{kg}$ and $100 \mathrm{mg} / \mathrm{kg}$ & $\mathrm{PO}$ & Mechanical HA & Complete reversal after 21 days & 125 \\
\hline Diabetic & $10 \mathrm{mg} / \mathrm{kg}$ to $100 \mathrm{mg} / \mathrm{kg}$ & $\mathrm{PO}$ & Dynamic AD & Dose-related reversal, near complete reversal at top dose & 24 \\
\hline Diabetic & $1 \mu \mathrm{g} / \mathrm{kg}$ to $100 \mu \mathrm{g} / \mathrm{kg}$ & IT & Dynamic AD & Dose-related reversal, near complete reversal at top dose & 24 \\
\hline Diabetic & $1 \mu \mathrm{g} / \mathrm{kg}$ to $100 \mu \mathrm{g} / \mathrm{kg}$ & IPL & Static and dynamic AD & No effect & 24 \\
\hline Acute herpetic pain (mous & use) $10 \mathrm{mg} / \mathrm{kg}$ to $100 \mathrm{mg} / \mathrm{kg}$ & $\mathrm{PO}$ & Mechanical $A D$ and $H A$ & Dose-related reversal, near complete reversal at top dose & 26 \\
\hline Acute herpetic pain (mous & use) $10 \mu \mathrm{g} / \mathrm{kg}$ to $100 \mu \mathrm{g} / \mathrm{kg}$ & IT & Mechanical AD and HA & Dose-related reversal, near complete reversal at top dose & 26 \\
\hline Acute herpetic pain (mous & use) $10 \mu \mathrm{g} / \mathrm{kg}$ to $100 \mu \mathrm{g} / \mathrm{kg} \quad \mathrm{IP}$ & PL/ICV/IC & Mechanical $A D$ and $H A$ & No effect & 26 \\
\hline PHN (mouse) & $30 \mathrm{mg} / \mathrm{kg}$ and $100 \mathrm{mg} / \mathrm{kg}$ & $\mathrm{PO}$ & Mechanical $A D$ and $H A$ & Complete reversal & 126 \\
\hline PHN & $10 \mathrm{mg} / \mathrm{kg}$ to $60 \mathrm{mg} / \mathrm{kg}$ & IP & Mechanical AD & Dose-related reversal, complete reversal at top dose & 25 \\
\hline $\mathrm{PHN}$ & $10 \mu \mathrm{g} / \mathrm{kg}$ to $30 \mu \mathrm{g} / \mathrm{kg}$ & IT & Mechanical AD & Dose-related reversal, complete reversal at top dose & 25 \\
\hline CIN (vincristine) & $100 \mu \mathrm{mol} / \mathrm{kg}$ to $400 \mu \mathrm{mol} / \mathrm{kg}$ & $\mathrm{PO}$ & Mechanical AD & $75 \%$ reversal & 127 \\
\hline CIN (paclitaxel) & Rep 100 mg/kg & IP & Mechanical AD & $50 \%$ reversal by third injection & 22 \\
\hline CIN (vincristine) & Rep 100 mg/kg & IP & Mechanical AD & $75 \%$ reversal by fourth injection & 22 \\
\hline
\end{tabular}

Studies have employed a variety of animal models of neuropathic pain induced by peripheral nerve trauma, diabetes (streptozocin), herpes zoster or chemotherapy. Unless otherwise stated, studies listed are single-dose behavioural studies performed in rats. For the majority of the studies, mechanical allodynia (AD) was assessed by von Frey stimulation, mechanical hyperalgesia (HA) by paw pressure (Randall-Selitto) test and heat HA by the plantar (Ugo Basile) test (cold AD was assessed by various methods). Mechanical AD refers to static mechanical AD unless otherwise stated. When possible, to aid study-to-study comparisons, the maximal effect observed has been described as a percentage reversal compared with normal (preinjury) baseline responses. CCI Chronic constriction injury to sciatic nerve; CCI-ION Chronic constriction injury to infraorbital nerve; CIN Chemotherapy-induced neuropathy; G-P Guinea pig; IC Intracisternal; ICV Intracerebroventricular; IP Intraperitoneal; IPL Intraplantar; IT Intrathecal; IV Intravenous; PHN Postherpetic neuralgia; PO Peroral; PSL Partial sciatic ligation; PWL Paw withdrawal latency; Rep Repeated dosing; SC Subcutaneous; SCI Spinal cord injury; SNI Spared nerve injury; SNL Spinal nerve ligation; TN Trigeminal neuralgia 
properties. Gabapentin was originally designed as an analogue
of the inhibitory neurotransmitter GABA to easily cross the blood brain barrier and mimic the effects of GABA. However, gabapentin does not bind to either $\mathrm{GABA}_{\mathrm{A}}$ or $\mathrm{GABA}_{\mathrm{B}}$ receptors (31-33) and neither does pregabalin (34). The antinociceptive effects of gabapentin in models of neuropathic pain were unaltered by administration of either a $\mathrm{GABA}_{\mathrm{A}}$ receptor antagonist (7) or a $\mathrm{GABA}_{\mathrm{B}}$ receptor antagonist $(7,35)$. Therefore, it is doubtful that gabapentin exerts its analgesic properties via GABA receptors, and current data indicate this is probably also true for pregabalin (34). The mechanisms of action of gabapentin and pregabalin have also been linked to the L-amino acid transporter, alpha-amino-3-hydroxy-5methyl-4-isoxazolepropionic acid (AMPA) receptors, $\mathrm{N}$-methylD-aspartate (NMDA) receptors and ATP-sensitive potassium channels (for review see [36]). However, conclusive data demonstrating definitive roles for these targets in the analgesic effects of gabapentin and pregabalin are lacking or contradictory.

Currently, the most likely mechanism underlying the analgesic effects of gabapentin and pregabalin involves the ubiquitous $\alpha_{2} \delta$ calcium channel subunit. It was first recognized that gabapentin could bind to a novel site in the brain (31), which was later identified to be the $\alpha_{2} \delta$ calcium channel subunit (37). In general, native neuronal voltage-gated calcium channels (VGCCs) consist of a main $\alpha_{1}$ pore-forming subunit (on which VGCC classification is based) with $\alpha_{2} \delta$ and $\beta$ subunits (38). There are four isoforms of the $\alpha_{2} \delta$ subunit with differential expression (33); of importance to sensory processing, $\alpha_{2} \delta-1$ and $\alpha_{2} \delta-2$ are highly expressed in small dorsal root ganglion (DRG) cells and $\alpha_{2} \delta-3$ is highly expressed in large DRG cells and the brain $(33,39)$. It has been shown that gabapentin and pregabalin bind with high affinity to $\alpha_{2} \delta-1$ and $\alpha_{2} \delta-2$ isoforms, but not $\alpha_{2} \delta-3$ and $\alpha_{2} \delta-4$ isoforms $(40,41)$ and, in addition, gabapentin binds with greater affinity to the $\alpha_{2} \delta-1$ subunit compared with the $\alpha_{2} \delta$-2 subunit (40).

There is substantial evidence for the role of the $\alpha_{2} \delta-1$ subunit of VGCCs, but not currently $\alpha_{2} \delta-2$, in the generation of neuropathic pain, and that gabapentin and pregabalin exert their analgesic effects through interaction with this subunit. There is a marked upregulation of $\alpha_{2} \delta$-1 expression in ipsilateral DRGs following both SNL (42) and PSL (43). Antisense oligonucleotides directed to $\alpha_{2} \delta-1$ blocked $\alpha_{2} \delta-1$ upregulation in the spinal cord and inhibited mechanical allodynia induced by SNL (44). Importantly, the upregulation of $\alpha_{2} \delta-1$ expression can be correlated to the antinociceptive effects of gabapentin (45). Specifically, in neuropathic pain models in which gabapentin was effective, (CCI, SNL and diabetic) an upregulation of $\alpha_{2} \delta-1$ expression was evident in the DRG or the spinal cord. In comparison, there was no such $\alpha_{2} \delta-1$ upregulation and gabapentin was ineffective in vincristine-induced neuropathic pain (45). However, others have reported a significant inhibition of vincristine-induced pain following repeated gabapentin administration (22) and a single dose pregabalin treatment (30), perhaps suggesting that the analgesic effects of these drugs do not occur via $\alpha_{2} \delta-1$ binding alone. The 217th amino acid, arginine, of the recombinant $\alpha_{2} \delta$ protein was found to be essential for gabapentin binding, because its substitution for alanine (R217A) markedly reduced gabapentin binding in brain membranes (33). Furthermore, R217A mutant mice developed mechanical allodynia following CCI, which was insensitive to pregabalin treatment, but was inhibited by morphine and amitriptyline (33).
The proposed consequence of gabapentin/pregabalin binding to $\alpha_{2} \delta$ subunits of VGCCs is a reduction in neurotransmitter release resulting in a decrease in neuronal hyperexcitability. Gabapentin has been shown to inhibit the evoked release of glutamate (46) and substance P (47) in the spinal cord of neuropathic rats. Spontaneous (ectopic) discharge occurs following peripheral nerve injury and, using electrophysiological techniques, studies have examined the effect of gabapentin/pregabalin on this phenomenon. In vitro, gabapentin has been shown to inhibit spontaneous discharges of A-fibres in chronically compressed DRG (48). In vivo, systemic gabapentin had no effect on the ectopic discharge from injured afferents $(18,47)$, yet inhibited the spontaneous activity of spinal (wide dynamic range [WDR]) neurons (49) in SNL rats. Following PSL, both systemic gabapentin and pregabalin inhibited the spontaneous discharge from injured afferents $(20,28)$.

Gabapentin's site of action is thought to occur at the spinal level, because analgesia following nerve injury is produced by systemic or spinal gabapentin administration, but not with an administration into the brain or periphery $(24,26)$. There is evidence to suggest that the spinal site of action has a presynaptic location (50). However, one study reported antinociceptive effects in PSL mice following intracerebroventricular gabapentin, suggesting an additional supraspinal site of action (51). In addition, this study demonstrated a significant role for the descending noradrenergic system and spinal $\alpha_{2}$-adrenergic receptors in the antinociceptive effects of gabapentin following nerve injury (51). Recently, it was elegantly demonstrated that the efficacy of gabapentin in neuropathic rats is dependent upon the integrity of a spino-bulbo-spinal circuit (52), which originates with neurokinin-1 (NK-1) expressing superficial dorsal horn neurons projecting to the brain and terminates with the activation of excitatory 5 -hydroxytryptamine $3\left(5-\mathrm{HT}_{3}\right)$ receptors in the spinal cord via descending 5-HT pathways. These pivotal studies $(51,52)$ demonstrate that the analgesic mechanism of gabapentin/pregabalin is unlikely to be solely due to $\alpha_{2} \delta$ interaction and further studies are required to determine its precise nature.

\section{CLINICAL EVIDENCE OF ANALGESIC EFFICACY IN NEUROPATHIC PAIN SYNDROMES}

Pain reduction during treatment with gabapentin or pregabalin has been reported in a wide variety of human neuropathic conditions, including diabetic polyneuropathy (DPN), PHN, various radiculopathies, complex regional pain syndrome (CRPS), phantom limb pain, central pain syndromes and trigeminal neuralgia (53). In the mid- to late 1990s, early evidence for gabapentin came in the form of uncontrolled case reports, case series, retrospective reviews and open-label trials $(53,54)$. Since 1998, however, more than two dozen prospective, double-blind, randomized, controlled trials (RCTs) have been published supporting analgesic efficacy of both gabapentin and pregabalin in many, but not all, neuropathic pain syndromes. Four gabapentin RCTs and seven pregabalin RCTs were industry-initiated or included authors from the drugs' manufacturers, Parke-Davis or Pfizer. We conducted a literature search using the Cochrane Central Register of Controlled Trials (2006, Issue 1) and MEDLINE database (1966 to January 2005). The database search strategies involved Boolean searches of: (gabapentin OR pregabalin) AND (neuropathic OR neuropathy OR neuralgia OR sciatica $\mathrm{OR}$ radiculopathy $\mathrm{OR}$ causalgia $\mathrm{OR}$ reflex sympathetic 
TABLE 2 COPYRIGHT PULSUS GROUP INC, = DO NOT COPY

Published randomized, controlled trials of gabapentin and pregabalin for painful diabetic neuropathy

\begin{tabular}{|c|c|c|c|c|c|c|c|}
\hline & \multicolumn{4}{|c|}{ Gabapentin (TID dosing) (rerference) } & \multicolumn{3}{|c|}{ Pregabalin (reference) } \\
\hline & 8 & 66 & 62 & 65 & 67 & 68 & 69 \\
\hline Study design & Parallel & Crossover & Crossover & Parallel & Parallel & Parallel & Parallel \\
\hline $\begin{array}{l}\text { Patients in each } \\
\text { category }(n)\end{array}$ & $\begin{array}{c}\text { Gabapentin 84; } \\
\text { Placebo } 81\end{array}$ & 40 & 25 & $\begin{array}{c}\text { Gabapentin } 30 \\
\text { Placebo } 30\end{array}$ & $\begin{array}{l}\text { Pregabalin } \\
75 \text { mg/day: } 77 \text {, } \\
300 \text { mg/day: } 81 \text {, } \\
600 \text { mg/day: } 82 ; \\
\text { Placebo } 97\end{array}$ & $\begin{array}{c}\text { Pregabalin: } 76 ; \\
\text { Placebo: } 70\end{array}$ & $\begin{array}{l}\text { Pregabalin } \\
150 \text { mg/day: } 79 \text {, } \\
600 \text { mg/day: } 82 ; \\
\text { Placebo } 85\end{array}$ \\
\hline $\begin{array}{l}\text { Treatment } \\
\text { control(s) }\end{array}$ & Placebo & Placebo & $\begin{array}{l}\text { Amitriptyline } \\
\text { (no placebo) }\end{array}$ & $\begin{array}{l}\text { Part I: placebo; } \\
\text { Part II: venla- } \\
\text { faxine + combil }\end{array}$ & $\begin{array}{l}\text { Placebo } \\
\text { Iation }\end{array}$ & Placebo & Placebo \\
\hline $\begin{array}{l}\text { Allowed } \\
\text { concomitant } \\
\text { medications }\end{array}$ & $\begin{array}{c}\text { Acetaminophen, } \\
\text { ASA, SSRIs }\end{array}$ & $\begin{array}{l}\text { NSAIDs, } \\
\text { opioids }\end{array}$ & Acetaminophen & None & $\begin{array}{l}\text { Acetaminophen, } \\
\text { SSRIs, gabapentin } \\
\text { treatment failures } \\
\text { excluded }\end{array}$ & $\begin{array}{l}\text { Acetaminophen, } \\
\text { ASA, SSRIs, } \\
\text { gabapentin } \\
\text { treatment failures } \\
\text { excluded }\end{array}$ & $\begin{array}{l}\text { ASA, } \\
\text { acetaminophen, } \\
\text { SSRIs }\end{array}$ \\
\hline Starting dose & 900 mg/day & Not specified & 300 mg/day & 300 mg/day & $\begin{array}{c}75 \text { mg/day: } 75 \text { mg/day, } \\
300 \text { mg/day: } \\
300 \text { mg/day, } \\
600 \text { mg/day: } \\
75 \text { mg/day }\end{array}$ & 100 mg TID & $\begin{array}{c}150 \mathrm{mg} / \text { day- } \\
25 \mathrm{mg} / \mathrm{day} \\
600 \mathrm{mg} / \mathrm{day}- \\
100 \mathrm{mg} / \text { day }\end{array}$ \\
\hline $\begin{array}{l}\text { Target } \\
\text { maintenance } \\
\text { dose }\end{array}$ & $\begin{array}{l}3600 \mathrm{mg} / \text { day } \\
\text { (reached by } \\
67 \% \text { of patients) }\end{array}$ & 900 mg/day & 1800 mg/day & 3600 mg/day & $\begin{array}{l}75 \text { mg/day: } 75 \text { mg/day; } \\
300 \text { mg/day: } \\
300 \text { mg/day; } \\
600 \text { mg/day: } \\
600 \text { mg/day; } \\
\text { (TID dosing) }\end{array}$ & 100 mg TID & $\begin{array}{c}150 \text { mg/day- } \\
150 \text { mg/day } \\
600 \mathrm{mg} / \text { day- } \\
600 \mathrm{mg} / \text { day } \\
\text { (TID dosing) }\end{array}$ \\
\hline Titration method & To MTD & Not specified & To MTD & To MTD & Forced to target & Forced to target & Forced? \\
\hline Titration duration & 4 weeks & Not specified & Not specified & 4 weeks & 1 week & None & 2 weeks \\
\hline Treatment duration & 8 weeks & 6 weeks & 6 weeks & 8 weeks & 5 weeks & 8 weeks & 6 weeks \\
\hline $\begin{array}{l}\text { Primary outcome } \\
\text { measure }\end{array}$ & $0-10$ NRS & $0-10 \mathrm{~cm}$ VAS & $\begin{array}{l}\text { Verbal pain } \\
\text { descriptors }\end{array}$ & $0-10$ NRS & $0-10$ NRS & $0-10$ NRS & 0-10 NRS \\
\hline $\begin{array}{l}\text { Study results* } \\
\text { (comments) }\end{array}$ & $\begin{array}{c}\text { Gabapentin > } \\
\text { placebo }\end{array}$ & $\begin{array}{l}\text { Gapapentin } \\
\text { vs placebo NS } \\
\text { (gabapentin > } \\
\text { placebo for } \\
\text { MPQ scores) }\end{array}$ & $\begin{array}{l}\text { Gabapentin vs } \\
\text { amytriptyline } \\
\text { NS }\end{array}$ & $\begin{array}{l}\text { Part I: Gabapenti } \\
\text { > placebo; } \\
\text { Part II: } \\
\text { Gabapentin/ } \\
\text { venlafaxine } \\
\text { > gabapentin }\end{array}$ & $\begin{array}{l}\text { Pregabalin > } \\
\text { placebo for } \\
300 \mathrm{mg} / \text { day } \\
\text { and } 600 \mathrm{mg} / \mathrm{day} \\
\text { only }\end{array}$ & $\begin{array}{l}\text { Pregabalin > } \\
\text { placebo }\end{array}$ & $\begin{array}{l}600 \mathrm{mg} / \mathrm{day}> \\
\text { placebo; } \\
150 \mathrm{mg} / \text { day } \\
\text { vs placebo } \\
\text { NS }\end{array}$ \\
\hline $\begin{array}{l}\text { Patients who } \\
\text { dropped out } \\
\text { due to AEs (\%) }\end{array}$ & 8.3 & Not specified & 16.7 & Not specified & $\begin{array}{l}75 \text { mg/day: } 2.6 \\
300 \text { mg/day: } 3.7 \\
600 \text { mg/day: } 12.2\end{array}$ & 10.5 & $\begin{array}{l}150 \mathrm{mg} / \mathrm{day}: 2.5 \\
600 \mathrm{mg} / \mathrm{day}: 8.5\end{array}$ \\
\hline Trial quality score ${ }^{\dagger}$ & 5 & 2 & 4 & 3 & 5 & 5 & 5 \\
\hline
\end{tabular}

*The symbol '>' denotes 'analgesic efficacy greater'; listed differences were reported as statistically significant unless otherwise stated; †See text for details. AEs Adverse events; ASA Acetylsalicylic acid; MPQ McGill Pain Questionnaire; MTD Maximally tolerated dose; NRS Numerical rating scale; NS Not statistically significant; NSAIDs Nonsteroidal anti-inflammatory drugs; SSRIs Selective serotonin reuptake inhibitors; TID Three times daily; VAS Visual analogue scale; vs Versus

dystrophy OR crps OR rsd OR complex regional pain syndrome); Field: All Fields; Limits: Randomized Controlled Trial, English language. Tables 2 to 5 list the RCTs included for review and the Appendix lists excluded publications along with reasons for exclusion. All included RCTs were evaluated by one of the authors (IG) and rated using a three-item (1 to 5) quality scale (55).

Diabetic neuropathy

DPN or distal symmetrical sensorimotor neuropathy is the most common neuropathy in patients with diabetes mellitus (56), and affects approximately 750 per 100,000 population in developed countries (57). DPN is associated with loss of peripheral neurons due to a variety of metabolic, autoimmune and ischemic causes (58). These disturbances are thought to cause pain by various possible mechanisms, including acute and ongoing neuronal degeneration (59), hyperexcitability of dysfunctional nociceptive afferent neurons (eg, C fibres) (60) or aberrant interactions between nociceptive (eg, $\mathrm{C}$ fibres) and non-nociceptive (eg, A-beta fibres) sensory afferent neurons (61). However, it is currently unclear why these changes lead to pain symptoms in only some diabetic neuropathy patients. In addition to antidepressants, opioids and other anticonvulsant drugs, gabapentin and pregabalin have been studied in multiple DPN RCTs. Table 2 includes three gabapentin and three pregabalin placebo-controlled RCTs in DPN. Table 2 also describes one nonplacebo-controlled trial comparing gabapentin with amitriptyline only (62). In addition to these, 
one gabapentin RCT (63) and one pregabalin RCT (64)
involved mixed populations of DPN (60\% to $70 \%)$ and PHN (30\% to $40 \%$ ) (Table 3 ).

Gabapentin: In two of the four placebo-controlled gabapentin RCTs, analgesic efficacy was statistically superior to placebo and accompanied by improvements in several secondary measures of quality of life, mood and sleep $(8,65)$. Backonja et al (8) reported a $39 \%$ pain reduction from baseline with gabapentin, significantly greater than the $22 \%$ pain reduction seen with placebo. Simpson (65) reported a $38 \%$ pain reduction from baseline with gabapentin, significantly greater than the $8 \%$ pain reduction seen with placebo. However, the gabapentin RCT by Gorson et al (66), which involved a maximum dose of $900 \mathrm{mg} /$ day, yielded no significant gabapentin-placebo difference for pain intensity but a significant difference for McGill Pain Questionnaire total scores in favour of gabapentin. Gilron et al (63) also reported no significant gabapentin-placebo difference for the primary efficacy measure ( 0 to 10 numerical rating scale) at a mean maximally tolerated gabapentin dose of $2207 \mathrm{mg} /$ day. This RCT employed an active placebo (lorazepam) which provides more effective blinding and may have resulted in a narrower gabapentinplacebo treatment difference than one might observe with an inert placebo. However, in this RCT, gabapentin was statistically superior to active placebo for several secondary outcome measures including the short-form McGill Pain Questionnaire, Brief Pain Inventory, Short Form-36 Health Survey and Beck Depression Inventory (63).

Pregabalin: Four large RCTs of pregabalin for DPN have been reported as completed (67-70), however, one of these is unpublished as yet and cited here as a meeting abstract (70). The three published RCTs (Table 2) reported statistically significant analgesic efficacy versus placebo with $34 \%$ to $40 \%$ pain reductions from baseline at pregabalin target doses of at least $300 \mathrm{mg} /$ day (67-69). In these RCTs, pain reduction was accompanied by improvements in sleep over similar dosage ranges and with a similar temporal profile (67-69). The mixed DPN/PHN pregabalin RCT reported similar results (Table 3) (64).

\section{PHN}

PHN affects approximately 300 per 100,000 of the population and affects $25 \%$ to $50 \%$ of adults (older than 50 years) with herpes zoster reactivation (57). PHN is perhaps the most dreaded complication of acute herpes zoster infection, which causes destruction of sensory neurons (71). A postmortem study of five patients who had previously experienced a herpes zoster infection described spinal cord dorsal horn damage, as well as peripheral nerve pathology, in the three patients who had developed PHN, but only peripheral nerve pathology in the two patients who did not develop PHN (72). Quantitative sensory testing studies in living patients (73) have described heterogeneous mechanisms of PHN, which may result in sensory loss, spontaneous pain and touch-evoked pain (allodynia). Furthermore, these heterogeneous mechanisms may even coexist in the same patient. In addition to antidepressants, opioids and other anticonvulsants, gabapentin and pregabalin have been studied in multiple PHN RCTs. Table 4 describes two gabapentin and three pregabalin RCTs in PHN.

Gabapentin: A total of 336 PHN patients received gabapentin in two well-powered RCTs; gabapentin demonstrated analgesic efficacy at target doses of $1800 \mathrm{mg} /$ day, $2400 \mathrm{mg} /$ day or
TABLE 3

Published randomized, controlled trials of gabapentin and pregabalin in mixed populations of painful diabetic neuropathy and postherpetic neuralgia

\begin{tabular}{|c|c|c|}
\hline & Gabapentin (63) & Pregabalin (64) \\
\hline Study design & Crossover & Parallel \\
\hline Patients (n) & 57 & $\begin{array}{l}\text { Flex: } 141 \text {; fixed: } 132 \\
\text { placebo: } 65\end{array}$ \\
\hline $\begin{array}{l}\text { Treatment } \\
\text { control(s) }\end{array}$ & $\begin{array}{l}\text { Active placebo } \\
\text { (Iorazepam) } \\
\text { Morphine-gabapentin } \\
\text { in combination }\end{array}$ & Placebo \\
\hline $\begin{array}{l}\text { Allowed } \\
\text { concomitant } \\
\text { medications }\end{array}$ & All allowed & $\begin{array}{l}\text { SSRIs, ASA, } \\
\text { benzodiazepines, } \\
\text { acetaminophen; } \\
\text { previous gabapentin } \\
\text { allowed }\end{array}$ \\
\hline Starting dose & $400 \mathrm{mg} /$ day & $\begin{array}{l}\text { Flex: } 150 \mathrm{mg} / \text { day; } \\
\text { Fixed: } 300 \mathrm{mg} / \text { day }\end{array}$ \\
\hline $\begin{array}{l}\text { Target } \\
\text { maintenance } \\
\text { dose }\end{array}$ & $\begin{array}{l}3200 \text { mg/day (mean MTD: } \\
2207 \text { mg/day) }\end{array}$ & $\begin{array}{l}\text { Flex: } 150-600 \mathrm{mg} / \mathrm{day} \text {; } \\
\text { Fixed: } 600 \mathrm{mg} / \mathrm{day} \\
\text { (BID dosing) }\end{array}$ \\
\hline Titration method & To MTD & $\begin{array}{l}\text { Flex: MTD; } \\
\text { Fixed: forced }\end{array}$ \\
\hline Titration duration & 3 weeks & $\begin{array}{l}\text { Flex: } 5 \text { weeks; } \\
\text { Fixed: } 2 \text { weeks }\end{array}$ \\
\hline Treatment duration & 4 weeks & 12 weeks \\
\hline Primary outcome & $0-10$ NRS & $0-10$ NRS \\
\hline
\end{tabular}

$\begin{array}{lcc}\begin{array}{c}\text { Study results* } \\ \text { (comments) }\end{array} & \begin{array}{c}\text { Gabapentin vs active } \\ \text { placebo NS (gabapentin }> \\ \text { active placebo for } \\ \text { SF-MPQ); gabapentin- } \\ \text { morphine > gabapentin }\end{array} & \begin{array}{l}\text { Flex and Fixed > } \\ \text { placebo; trend for } \\ \text { fewer AEs (NS) } \\ \text { in Flex group }\end{array} \\ \begin{array}{l}\text { Patients dropped } \\ \text { out due to AEs (\%) }\end{array} & 5.3 & \text { Flex: 17.0; Fixed: } 25 \\ \text { Trial quality score } & 5 & 4\end{array}$

'The symbol '>' enotes 'analgesic efficacy greater'; listed differences were reported as statistically significant unless otherwise stated; tSee text for details. AEs Adverse events; ASA Acetylsalicylic acid; BID Twice daily; Fixed Forced titration to maximal target dose; Flex Flexible dose titration to maximally tolerated dose (MTD); NRS Numerical rating scale; NS Not statistically significant; SFMPQ Short Form McGill Pain Questionnaire; SSRIs Selective serotonin reuptake inhibitors; vs Versus

$3600 \mathrm{mg} /$ day (Table 4) $(9,74)$. Pain reduction from baseline was reported to be $33 \%$ to $35 \%$ in all three of these dose groups. Improvements in sleep and several Short Form-36 quality of life domains were also reported $(9,74)$.

Pregabalin: Three large RCTs have demonstrated analgesic efficacy in PHN (75-77) (Table 4) with pain reductions from baseline which varied from $18 \%$ at $150 \mathrm{mg} /$ day (77) to $37 \%$ at $600 \mathrm{mg} /$ day (75). Again, pain relief was accompanied by improved sleep over similar dosage ranges and with a similar temporal profile.

Other neuropathic pain syndromes

The great majority of neuropathic pain RCTs of drug treatments have been conducted in patients with DPN or PHN. However, it has been recognized that not all drugs effective against DPN or PHN are effective in other neuropathic pain 
TABLE 4

COPYRIGHT PULSUS GROUP INC, = DO NOT COPY

Published randomized, controlled trials of gabapentin and pregabalin for postherpetic neuralgia

\begin{tabular}{|c|c|c|c|c|c|}
\hline & \multicolumn{2}{|c|}{ Gabapentin (reference) } & \multicolumn{3}{|c|}{ Pregabalin (reference) } \\
\hline & 9 & 74 & 75 & 76 & 77 \\
\hline Study design & Parallel & Parallel & Parallel & Parallel & Parallel \\
\hline $\begin{array}{l}\text { Patients in } \\
\text { each category }(n)\end{array}$ & $\begin{array}{l}\text { Gabapentin } 113 \\
\text { placebo } 116\end{array}$ & $\begin{array}{l}2400 \text { mg/day } 108 ; \\
1800 \text { mg/day } 115 ; \\
\text { placebo } 111\end{array}$ & $\begin{array}{c}\text { Pregabalin } 89 \\
\text { placebo } 84\end{array}$ & $\begin{array}{l}\text { Pregabalin } 150 \text { mg/day 81; } \\
\text { pregabalin } 300 \text { mg/day } 76 \text {; } \\
\text { placebo } 81\end{array}$ & $\begin{array}{r}\text { Pregabalin } 150 \text { mg/day } 87 ; \\
\text { pregabalin } 300 \text { mg/day } 98 \\
\text { pregabalin } 600 \text { mg/day } 90\end{array}$ \\
\hline Treatment control(s) & Placebo & Placebo & Placebo & Placebo & Placebo \\
\hline $\begin{array}{l}\text { Allowed } \\
\text { concomitant } \\
\text { medications }\end{array}$ & TCAs, opioids & $\begin{array}{l}\text { NSAIDs, weak } \\
\text { opioids, } \\
\text { antidepressants, } \\
\text { ASA }\end{array}$ & $\begin{array}{l}\text { Opioids, antidepressants, } \\
\text { NSAIDs, acetaminophen; } \\
\text { gabapentin treatment } \\
\text { failures excluded }\end{array}$ & $\begin{array}{l}\text { All but benzodiazepines } \\
\text { and AEDs prohibited; } \\
\text { gabapentin treatment } \\
\text { failures excluded }\end{array}$ & $\begin{array}{l}\text { NSAIDs, } \\
\text { acetaminophen, } \\
\text { opioids, } \\
\text { antidepressants }\end{array}$ \\
\hline Starting dose & 900 mg/day & 300 mg/day & $50 \mathrm{mg}$ TID & $\begin{array}{l}150 \text { mg/day-50 mg TID, } \\
300 \text { mg/day-100 mg TID }\end{array}$ & Titration not described \\
\hline $\begin{array}{l}\text { Target maintenance } \\
\text { dose }\end{array}$ & $\begin{array}{c}3600 \mathrm{mg} / \mathrm{day} \\
\text { (reached } \\
\text { by } 65 \% \text { ) }\end{array}$ & $\begin{array}{l}1 \text { group: } 1800 \text { mg/day; } \\
1 \text { group: } 2400 \text { mg/day }\end{array}$ & $\begin{array}{l}200 \text { mg TID }(\mathrm{CrCl}>60) \\
100 \text { mg TID }(\mathrm{CrCl} \leq 60)\end{array}$ & $\begin{array}{l}150 \text { mg/day-150 mg/day } \\
300 \text { mg/day-300 mg/day } \\
\text { (TID dosing) }\end{array}$ & $\begin{array}{l}\text { Titration not described } \\
\text { (BID dosing) }\end{array}$ \\
\hline Titration method & To MTD & Forced to target dose & Forced to target dose & Forced to target dose & Titration not described \\
\hline Titration duration & 4 weeks & 2-3 weeks & $1-2$ weeks & 1 week & Titration not described \\
\hline Treatment duration & 8 weeks & 7 weeks & 8 weeks & 8 weeks & 13 weeks \\
\hline Primary outcome & 0-10 NRS & 0-10 NRS & 0-10 NRS & $0-10$ NRS & 0-10 NRS \\
\hline $\begin{array}{l}\text { Study results* } \\
\text { (comments) }\end{array}$ & $\begin{array}{l}\text { Gabapentin > } \\
\text { placebo }\end{array}$ & $\begin{array}{l}\text { Gabapentin > } \\
\text { placebo at both } \\
1800 \mathrm{mg} / \text { day and } \\
2400 \mathrm{mg} / \text { day }\end{array}$ & $\begin{array}{c}\text { Pregabalin > } \\
\text { placebo }\end{array}$ & $\begin{array}{l}\text { Pregabalin > placebo; } \\
\text { minimal difference } \\
150 \mathrm{mg} / \text { day } \\
\text { vs } 300 \mathrm{mg} / \text { day }\end{array}$ & $\begin{array}{c}150 \mathrm{mg} / \mathrm{day}-600 \mathrm{mg} / \mathrm{day}> \\
\text { placebo, dose response } \\
\text { apparent but not } \\
\text { statistically reported }\end{array}$ \\
\hline $\begin{array}{l}\text { Patients } \\
\text { dropped out due } \\
\text { to AEs (\%) }\end{array}$ & 18.6 & $\begin{array}{l}1800 \text { mg/day 13; } \\
2400 \text { mg/day } 17.6\end{array}$ & 31.5 & $\begin{array}{l}150 \mathrm{mg} / \text { day } 11.1 ; \\
300 \mathrm{mg} / \text { day } 15.4\end{array}$ & $\begin{array}{l}150 \mathrm{mg} / \text { day } 8.0 \\
300 \mathrm{mg} / \text { day } 15.3 \\
600 \mathrm{mg} / \text { day } 21.1\end{array}$ \\
\hline Trial quality score $^{\dagger}$ & 5 & 5 & 5 & 5 & 3 \\
\hline
\end{tabular}

*The symbol '>' denotes 'analgesic efficacy greater'; listed differences were reported as statistically significant unless otherwise stated; ${ }^{\dagger}$ See text for details. AEs Adverse events; ASA Acetylsalicylic acid; BID Twice daily; CrCl Creatinine clearance; MTD Maximally tolerated dose; NRS Numerical rating scale; NSAIDs Nonsteroidal anti-inflammatory drugs; TCAs Tricyclic antidepressants; vs Versus

syndromes $(78,79)$. Thus, several clinical investigators have attempted to evaluate the efficacy of gabapentin (but not pregabalin, as yet) in other neuropathic pain syndromes. Table 5 lists eight published RCTs of gabapentin in other neuropathic pain syndromes (80-87). Pain reduction with gabapentin was reported to be superior to placebo in single RCTs of phantom limb pain (81), Guillain-Barré Syndrome (83), cancer-related neuropathic pain (85) and mixed neuropathies (82). Levendoglu et al (84) reported a positive result in SCI patients, whereas a smaller SCI trial failed to show significant differences in pain intensity, possibly due to inadequate statistical power (80). Gabapentin appeared to demonstrate slight, statistically insignificant superiority over placebo in a single RCT of patients with CRPS type I (86). In a small RCT ( $n=11$ to 15 per group) of HIV-associated neuropathy, pain reduction from baseline was reported as $44.1 \%$ with gabapentin and $29.8 \%$ with placebo. However, the gabapentin versus placebo difference in pain reduction was not statistically significant (87).

Comparative and combination trials

In addition to placebo controls, few RCTs have compared gabapentin with other drugs. At the time of writing, no comparative RCTs of pregabalin have been published. Gilron et al (63) demonstrated that neuropathic pain intensity was significantly lower during treatment with morphine and gabapentin combination than with gabapentin alone. In addition, a trend favouring morphine alone over gabapentin alone was observed (63). In 11 gabapentin nonresponders, Simpson (65) conducted a second-stage trial and reported that a venlafaxine and gabapentin combination was superior to gabapentin alone in this group. Finally, in a nonplacebo-controlled trial, Morello et al (62) observed a slight trend suggesting superior pain reduction with amitriptyline versus gabapentin; however, this difference was not statistically significant.

\section{Pooled efficacy estimates}

Finnerup et al (78) recently conducted a systematic review of pharmacological treatments for neuropathic pain that calculated numbers needed to treat (NNT - the number of patients that need to be treated with a certain drug [compared with placebo] to obtain one patient with at least $50 \%$ pain relief) and that included 10 of the 15 gabapentin RCTs and five of the seven pregabalin RCTs reviewed here (78). Their initial NNT estimate for all doses of gabapentin was 5.1 (4.1 to 6.8); however, after excluding the low-dose RCT ( $900 \mathrm{mg} /$ day) by Gorson et al (66) and the lower dose arm (1800 mg/day) of the Rice et al (74) RCT, a revised NNT estimate for gabapentin was reported as 3.8 (3.1 to 5.1) (78). The NNT for pregabalin, including doses ranging from $150 \mathrm{mg} /$ day to $600 \mathrm{mg} /$ day, was estimated to be 4.2 (3.4 to 5.4) (78). These NNT values suggest that approximately four patients with neuropathic pain need to be treated with gabapentin or pregabalin to achieve one patient with at least $50 \%$ pain relief. Comparison with estimates for other drugs suggest that the efficacy of gabapentin and pregabalin is perhaps slightly less than that of tricyclic antidepressants $(\mathrm{NNT}=2$ to 3$)$ or morphine $(\mathrm{NNT}=2.5)(78)$. 
TABLE 5

COPYRIGHT PULSUS GROUP INC, " DO NOT COPY

Published randomized, controlled trials of gabapentin for other neuropathic pain syndromes

\begin{tabular}{|c|c|c|c|c|c|c|c|c|}
\hline & \multicolumn{7}{|c|}{ References } & \multirow[b]{2}{*}{87} \\
\hline & 80 & 81 & 82 & 83 & 84 & 85 & 86 & \\
\hline Pain syndrome & $\mathrm{SCl}$ & PLP & Mixed & Guillain-Barre & $\mathrm{SCl}$ & Ca-NP & CRPS-1 & HIV-NP \\
\hline Study design & Crossover & Crossover & Parallel & Crossover & Crossover & Parallel & Crossover & Parallel \\
\hline Patients (n) & 14 & 19 & $\begin{array}{c}\text { Gabapentin: } 153 ; \\
\text { placebo:152 }\end{array}$ & 18 & 20 & $\begin{array}{c}\text { Gabapentin: } 79 \text {, } \\
\text { placebo } 41\end{array}$ & 58 & $\begin{array}{l}\text { Gabapentin: } 15 ; \\
\text { placebo: } 11\end{array}$ \\
\hline Treatment control(s) & Placebo & Placebo & Placebo & Placebo & Placebo & Placebo & Placebo & Placebo \\
\hline $\begin{array}{l}\text { Allowed } \\
\text { concomitant } \\
\text { medications }\end{array}$ & None prohibited & TCAs & $\begin{array}{l}\text { TCAs, SSRIs, } \\
\text { ASA, NSAIDs, } \\
\text { weak opioids }\end{array}$ & Fentanyl & $\begin{array}{l}\text { None } \\
\text { allowed }\end{array}$ & $\begin{array}{l}\text { None } \\
\text { prohibited }\end{array}$ & $\begin{array}{l}\text { None } \\
\text { prohibited }\end{array}$ & $\begin{array}{l}\text { NSAIDs, } \\
\text { acetaminophen }\end{array}$ \\
\hline Starting dose & 300 mg/day & 300 mg/day & 300 mg/day & 15 mg/kg/day & Not specified & 600 mg/day & 600 mg/day & 400 mg/day \\
\hline $\begin{array}{l}\text { Target } \\
\text { maintenance } \\
\text { dose }\end{array}$ & 1800 mg/day & 2400 mg/day & 2400 mg/day & $15 \mathrm{mg} / \mathrm{kg} /$ day? & $\begin{array}{l}3600 \mathrm{mg} / \text { day } \\
\text { (mean MTD } \\
2850 \mathrm{mg} / \text { day }\end{array}$ & 1800 mg/day & 1800 mg/day & 2400 mg/day \\
\hline Titration method & To MTD & To MTD & To MTD & Not specified & To MTD & To MTD & Not specified & To MTD \\
\hline Titration duration & Not specified & Not specified & 5 weeks & none & 4 weeks & Not specified & Not specified & 2-3 weeks \\
\hline Treatment duration & 4 weeks & 6 weeks & 8 weeks & 1 week & 8 weeks & 10 days & 3 weeks & 4 weeks \\
\hline $\begin{array}{l}\text { Primary } \\
\text { outcome } \\
\text { measure }\end{array}$ & $\begin{array}{l}\text { Neuropathic pain } \\
\text { scale }\end{array}$ & $\begin{array}{l}\text { VAS } \\
\qquad 0-10 \mathrm{~cm}\end{array}$ & $0-10$ NRS & $0-10$ NRS & $\begin{array}{l}\text { VAS } \\
\qquad 0-100 \mathrm{~mm}\end{array}$ & $0-10$ NRS & $\begin{array}{l}\text { VAS } \\
\qquad 0-100 \mathrm{~mm}\end{array}$ & $\begin{array}{l}\text { VAS } \\
\qquad 0-10 \mathrm{~cm}\end{array}$ \\
\hline $\begin{array}{l}\text { Study results* } \\
\text { (comments) }\end{array}$ & $\begin{array}{l}\text { Gabapentin vs } \\
\text { placebo NS; } \\
\text { (gabapentin > } \\
\text { placebo for } \\
\text { "unpleasant } \\
\text { sensation" only) }\end{array}$ & $\begin{array}{c}\text { Gabapentin > } \\
\text { placebo }\end{array}$ & $\begin{array}{c}\text { Gabapentin > } \\
\text { placebo }\end{array}$ & $\begin{array}{l}\text { Gabapentin > } \\
\text { placebo }\end{array}$ & $\begin{array}{l}\text { Gabapentin > } \\
\text { placebo } \\
\text { (minimal } \\
\text { placebo } \\
\text { response) }\end{array}$ & $\begin{array}{c}\text { Gabapentin > } \\
\text { placebo }\end{array}$ & $\begin{array}{l}\text { Gabapentin vs } \\
\text { placebo NS } \\
\text { (apparent } \\
\text { reversal of } \\
\text { quantitative s } \\
\text { deficit by gab }\end{array}$ & $\begin{array}{l}\text { Gabapentin vs } \\
\text { placebo NS } \\
\text { ensory } \\
\text { apentin) }\end{array}$ \\
\hline $\begin{array}{l}\text { Patients dropped } \\
\text { out due to AEs (\%) }\end{array}$ & Not specified & Not specified & 15.7 & Not specified & None & 7.6 & 5.2 & 7.1 \\
\hline Trial quality score $^{\dagger}$ & 4 & 5 & 5 & 3 & 4 & 5 & 5 & 5 \\
\hline
\end{tabular}

*The symbol '>'denotes 'analgesic efficacy greater'; listed differences were reported as statistically significant unless otherwise stated; tSee text for details. AEs Adverse events; ASA Acetylsalicylic acid; Ca-NP Cancer-related neuropathic pain; CRPS-1 Complex regional pain syndrome type 1; HIV-NP Human immunodeficiency-related neuropathic pain; Mixed Mixed population of various different neuropathic pain syndromes; MTD Maximally tolerated dose; NRS Numerical rating scale; NS Not statistically significant; NSAIDs Nonsteroidal anti-inflammatory drugs; PLP Phantom limb pain; SCI Spinal cord injury; SSRIs Selective serotonin reuptake inhibitors; TCAs Tricyclic antidepressants; VAS Visual analogue scale; vs Versus

\section{Gabapentin}

After more than one decade of marketing and widespread international use, gabapentin appears to be a considerably safe and well-tolerated drug. Of interest, one case of gabapentin overdose did not result in serious toxicity (88). While it is often very difficult to demonstrate treatment-related causality with individual adverse events, several adverse event reports involving gabapentin bear mentioning. First, multiple case reports have described various adverse events following abrupt (89-92) or even tapered (93) gabapentin discontinuation, including tachycardia, diaphoresis, headache, gastrointestinal cramps, catatonia and, in one case, status epilepticus in the absence of a pre-existing seizure disorder (91). Several reports have suggested that gabapentin may induce various movement disorders, including myoclonus, dystonia and asterixis (94-98), which may be a cause of falls (98). Two different case reports $(99,100)$ have suggested that gabapentin may exacerbate myasthenia gravis, and individual case reports have implicated gabapentin as contributing to psychomotor agitation (101), renal allograft dysfunction (102), amenorrhea (103), arthralgia (104), aggressive behaviour in children (105), painful gynecomastia (106), cutaneous leukocytoclastic vasculitis (107) and neutropenia (108).
In the setting of neuropathic pain treatment, Table 6 describes adverse event frequencies from published gabapentin RCTs in neuropathic pain. Similar to the setting of epilepsy treatment (109), these data indicate that the most common adverse effects of gabapentin are somnolence and dizziness or ataxia. These symptoms are generally dose-related and reversible following dose reduction. Various other adverse events have been reported in more than $10 \%$ of patients, in at least two RCTs, including peripheral edema, lethargy, headache and diarrhea (Table 6). However, these events were not necessarily significantly more frequent than with placebo. Gabapentin treatment did not appear to adversely affect glycemic control in diabetic patients (8). Parsons et al (110) conducted a pooled analysis of adverse events in 603 PHN patients (358 received gabapentin and 245 received placebo) from three different RCTs. The results of this analysis indicated that the three most common adverse events were dizziness, somnolence and peripheral edema. Peripheral edema was significantly more frequent at doses of $1800 \mathrm{mg} /$ day or greater. Dizziness and somnolence, however, were most often first reported at doses less than $1800 \mathrm{mg} /$ day and, in patients ultimately titrated to doses $1800 \mathrm{mg} /$ day or greater, new-onset or worsening dizziness or somnolence were not more frequent than with placebo at 
TABLE 6

COPYRIGHT PULSUS GROUP INC, D DO NOT COPY

Adverse event frequencies from neuropathic pain randomized, controlled trials (RCTs) of gabapentin

\begin{tabular}{|c|c|c|c|c|c|c|c|c|c|c|c|c|c|c|c|}
\hline & \multicolumn{15}{|c|}{ References } \\
\hline Dizziness & 24 & $24^{*}$ & & 28 & 22 & 33 & NR & 11 & 24 & & & 9 & $37^{*}$ & $80^{*}$ & 6 \\
\hline Ataxia & 7 & & 8 & 20 & & 11 & NR & & & & & & & 47 & 2 \\
\hline Peripheral edema & 10 & & & 12 & & 11 & $N R$ & & & & 15 & & & & 2 \\
\hline Lethargy & & & & 16 & & & $N R$ & & & & & & $20^{*}$ & & \\
\hline Diarrhea & & 11 & & 8 & 12 & 5 & $N R$ & & 5 & & & 1 & & & \\
\hline Postural hypotension & & & & 24 & & & $N R$ & & & & & & & & \\
\hline Constipation & & & & 16 & & & $N R$ & & & & & & & & 4 \\
\hline Asthenia & & & & & & 6 & $N R$ & & & & 25 & & & & \\
\hline Fatigue & & & 10 & & & & $N R$ & & & & & & & & \\
\hline Accidental injury & & & 10 & & & & $N R$ & & 6 & & & & & & \\
\hline Vertigo & & & & & & & NR & & & & 15 & & & & \\
\hline Infection & 8 & & 10 & & & & NR & & 9 & & & 3 & & & \\
\hline Dry mouth & & & & & & 5 & NR & & & & & & & & 8 \\
\hline Blurry vision & & & & & & & $N R$ & & & & & & & & 2 \\
\hline
\end{tabular}

Data presented indicate percentage of patients receiving drug and reporting the listed adverse event. Note: Reported adverse event may differ across $R C T s$ in part, due to differences in adverse event evaluation which may vary from spontaneous patient reporting to open-ended patient questioning by researchers to specific questioning about each listed adverse event. Original percentages are rounded up. *Incidence of adverse event significantly more frequent than with placebo. NR Not reported

doses $1800 \mathrm{mg} /$ day or greater (110). This may suggest that tolerable dizziness or somnolence occurring early during gabapentin dose titration does not necessarily preclude further dose increases. The recent systematic review by Finnerup et al (78) estimated gabapentin's number needed to harm (the number of patients that need to be treated with a certain drug [compared with placebo] for one patient to drop out due to adverse effects) at 26.1 (14.1 to 170).

\section{Pregabalin}

Pregabalin has only recently been approved in several countries. Therefore, substantially fewer postmarketing safety data are available compared with gabapentin, and current estimates of safety come largely from RCTs of neuropathic pain, epilepsy and generalized anxiety disorder. Quite similar to gabapentin, the most frequent adverse events described with pregabalin include somnolence, dizziness, ataxia and peripheral edema (111). Early case reports have suggested that pregabalin, like gabapentin, may induce movement disorders such as myoclonus (112) and asterixis (113), and a single case report has described encephalopathy and edema of the splenium of the corpus callosum following abrupt discontinuation of pregabalin (114). Finally, limited evidence suggesting subjective drug 'liking' in a study of pregabalin in recreational sedative or hypnotic drug users as well as withdrawal symptoms upon pregabalin discontinuation has led the United States Drug Enforcement Administration to list pregabalin as a Schedule V narcotic of the Controlled Substances Act (low potential for abuse) (111). However, less than $5 \%$ of patients from all pregabalin RCTs reported euphoria as an adverse event.

In the setting of neuropathic pain treatment, Table 7 describes adverse event frequencies from published pregabalin
RCTs in neuropathic pain. These data indicate that the most common adverse effects of pregabalin, similar to gabapentin, are somnolence, dizziness and peripheral edema. Various other adverse events have been reported in more than $10 \%$ of patients, in at least two RCTs, including headache, weight gain and dry mouth (Table 7). However, these events were not necessarily significantly more frequent than with placebo. Pregabalin treatment did not appear to adversely affect glycemic control in diabetic patients (68). The recent systematic review by Finnerup et al (78) estimated pregabalin's number needed to harm at 11.7 (8.3 to 19.9) suggesting considerably higher study withdrawal rates than for gabapentin.

\section{PRESCRIBING CONSIDERATIONS FOR GABAPENTIN AND PREGABALIN IN NEUROPATHIC PAIN}

Treatment of neuropathic pain should be individualized to each patient concurrent with ongoing diagnostic evaluation, patient education and reassurance (79). Current clinical thinking supports multimodal, multidisciplinary therapy which includes drug treatment $(115,116)$. Gabapentin and pregabalin have been recommended as first-line drugs for neuropathic pain along with topical lidocaine, tricyclic antidepressants and serotonin-noradrenaline reuptake inhibitors $(78,79)$. While comparative estimates suggest that tricyclic antidepressants may be more efficacious than gabapentin or pregabalin, the drug interaction and side effect profiles of gabapentin and pregabalin appear to be more favourable (78).

Table 8 lists some basic information regarding the clinical pharmacology of gabapentin and pregabalin; however, clinicians 
TABLE 7

COPYRIGHT PULSUS GROUP INC, " DO NOT COPY

Adverse event frequencies from neuropathic pain randomized, controlled trials (RCTs) of pregabalin

\begin{tabular}{|c|c|c|c|c|c|c|c|}
\hline & \multicolumn{7}{|c|}{ References } \\
\hline & \multirow{2}{*}{$\begin{array}{c}67 \\
(600 \mathrm{mg} / \text { day })\end{array}$} & \multicolumn{3}{|c|}{69} & \multirow{2}{*}{$\begin{array}{c}76 \\
(300 \mathrm{mg} / \text { day })\end{array}$} & \multirow{2}{*}{$\begin{array}{c}77 \\
(600 \mathrm{mg} / \text { day })\end{array}$} & \multirow[b]{2}{*}{64} \\
\hline & & 68 & (600 mg/day) & 75 & & & \\
\hline Dizziness & 39 & 36 & 38 & 28 & 28 & 37 & 24 \\
\hline Somnolence & 27 & 20 & 22 & 25 & 24 & 26 & 12 \\
\hline Peripheral edema & 13 & 11 & 17 & 19 & 13 & & 12 \\
\hline Headache & 10 & 7 & 16 & 8 & 11 & 4 & 4 \\
\hline Weight gain & & & 10 & & & 9 & 13 \\
\hline Dry mouth & 5 & & 9 & 11 & 7 & 12 & 4 \\
\hline Ataxia & 9 & & & 7 & & 12 & \\
\hline Constipation & 9 & 5 & 6 & & & 9 & \\
\hline \multicolumn{8}{|l|}{ Lethargy } \\
\hline Diarrhea & 4 & 4 & 2 & 7 & 5 & & \\
\hline Asthenia & 7 & 4 & 12 & & 3 & 6 & 8 \\
\hline \multicolumn{8}{|l|}{ Fatigue } \\
\hline Accidental injury & 5 & 4 & 10 & & & & \\
\hline Abnormal gait & & & & 8 & & 4 & \\
\hline Confusion & 9 & & & 7 & & 3 & \\
\hline Cognitive dysfunction & & & & & & 4 & \\
\hline Nausea & & 8 & & & & 2 & 8 \\
\hline Vertigo & & & & & & & 9 \\
\hline Infection & 1 & 15 & 6 & & 7 & & \\
\hline Blurry vision & 9 & 5 & 9 & 11 & & 6 & \\
\hline
\end{tabular}

Data presented indicate percentage of patients receiving drug and reporting the listed adverse event. Note: Reported adverse event may differ across RCTs, in part, due to differences in adverse event evaluation that may vary from spontaneous patient reporting to open-ended patient questioning by researchers to specific questioning about each listed adverse event. Original percentages are rounded up. *Incidence of adverse event significantly more frequent than with placebo

TABLE 8

Clinical pharmacology of gabapentin and pregabalin

\begin{tabular}{|c|c|c|}
\hline & Gabapentin $(117,128)$ & Pregabalin $(34,129)$ \\
\hline Time to maximal absorption & $2 \mathrm{~h}$ to $3 \mathrm{~h}$ & $0.8 \mathrm{~h}$ to $1.4 \mathrm{~h}$ \\
\hline Oral bioavailability & $57 \%$ after single $300 \mathrm{mg}$ dose, $42 \%$ after single $600 \mathrm{mg}$ dose & $>90 \%$ independent of dose \\
\hline \multirow[t]{3}{*}{ Metabolism and elimination } & - Negligible metabolism & - Negligible metabolism \\
\hline & - Renally excreted unchanged & - Renally excreted unchanged \\
\hline & - Elimination half-life $5 \mathrm{~h}$ to $9 \mathrm{~h}$ & - Elimination half-life $4 \mathrm{~h}$ to $7 \mathrm{~h}$ \\
\hline Drug interactions & - Oral antacids reduce bioavailability by $20 \%$ to $30 \%$ & - No significant drug interactions described to date \\
\hline \multirow[t]{2}{*}{ Starting dose } & - $100 \mathrm{mg} /$ day to $900 \mathrm{mg} / \mathrm{day}$ & - $75 \mathrm{mg} /$ day to $150 \mathrm{mg} /$ day \\
\hline & - Dose reduction required with renal insufficiency & - Dose reduction required with renal insufficiency \\
\hline \multirow[t]{2}{*}{ Titration } & - Titrate toward MTD over several weeks & - Titrate toward MTD over several weeks \\
\hline & - Increaseweekly by $300 \mathrm{mg} /$ day to $900 \mathrm{mg} / \mathrm{day}$ & - Increase weekly by $50 \mathrm{mg} /$ day to $150 \mathrm{mg} /$ day \\
\hline Dosage frequency & Every $8 \mathrm{~h}$ & Every $8 \mathrm{~h}$ to $12 \mathrm{~h}$ \\
\hline Usual effective dose & $1200 \mathrm{mg} /$ day to $2400 \mathrm{mg} /$ day & $150 \mathrm{mg} /$ day to $600 \mathrm{mg} /$ day \\
\hline Maximum dose & 3600 mg/day & 600 mg/day \\
\hline
\end{tabular}

MTD Maximally tolerated dose

are urged to consult the product monograph before prescribing these medications. Advantages of gabapentin and pregabalin include negligible metabolism, no hepatic enzyme inhibition or induction and, thus, no clinically important drug interactions $(34,117)$. However, the bioavailability of gabapentin is known to diminish by $20 \%$ to $30 \%$ with concomitant oral antacid administration (117). Both drugs are excreted unchanged in the urine and, therefore, dose should be reduced proportionally to creatinine clearance in the presence of renal insufficiency $(34,117)$. Absorption of pregabalin is quite fast (approximately $1 \mathrm{~h}$ to maximal absorption) and oral bioavailability remains very high (greater than $90 \%$ ) regardless of dose. In contrast, absorption of gabapentin is slightly slower ( $2 \mathrm{~h}$ to $3 \mathrm{~h}$ to maximal absorption) and occurs through a saturable transport system in the gastrointestinal tract such that bioavailability decreases with increasing doses (118). Therefore, gabapentin dose increases in higher dose ranges should be expected to lead to incrementally smaller increases in plasma drug concentrations. RCTs of gabapentin and pregabalin have used starting doses of at least $300 \mathrm{mg} /$ day and $75 \mathrm{mg} /$ day, respectively (Tables 2 to 5). However, in elderly patients, patients with renal insufficiency or patients already receiving sedating drugs, one should consider starting with even lower doses than these and be titrated very slowly to minimize the risk of falling and related trauma. Evidence suggests that flexible dose titration toward individual maximally tolerated doses leads to fewer adverse events than fixed titration to a specific target dose (64). The elimination half-lives of gabapentin and pregabalin ( $5 \mathrm{~h}$ to $9 \mathrm{~h}$ and $4 \mathrm{~h}$ to $7 \mathrm{~h}$, respectively) lend themselves to three times daily dosing. Two recent 
pregabalin RCTs have demonstrated superiority over placebo with twice daily dosing $(64,77)$. However, these trials used a retrospective $24 \mathrm{~h}$ pain intensity measure each morning, so the possibility of important breakthrough pain with twice daily dosing has not been ruled out. Gabapentin and pregabalin RCT results collectively suggest that analgesic efficacy is dosedependent across the doses studied (Tables 2 to 5). Usual effective, and tolerable, doses range from $1200 \mathrm{mg} /$ day to $2400 \mathrm{mg} /$ day for gabapentin and $150 \mathrm{mg} /$ day to $600 \mathrm{mg} /$ day for pregabalin; doses greater than $3600 \mathrm{mg} /$ day and $600 \mathrm{mg} /$ day, respectively, have not been studied (Table 8).

\section{CONCLUSIONS}

Gabapentin and pregabalin represent a relatively novel class of drugs for the treatment of neuropathic pain. Laboratory evidence demonstrates that gabapentin and pregabalin can inhibit different neuropathic pain behaviours in a broad range of neuropathic pain models. Their analgesic effects are thought to be elicited via their binding to the $\alpha_{2} \delta$ subunit of VGCCs which is considered to decrease neurotransmitter release, thus reducing neuronal hyperexcitability. The majority of clinical evidence supports analgesic efficacy in DPN and PHN and limited evidence suggests that this efficacy extends to other, but not necessarily all, neuropathic pain syndromes. Early comparative RCTs and pooled estimates from meta-analyses suggest that analgesic efficacy of gabapentin and pregabalin is perhaps slightly lower than that of tricyclic antidepressants or opioids. However, the most attractive aspects of these two drugs include their tolerability, lack of serious toxicity and ease of use. Future research efforts are warranted to fully understand the mechanism of action of these drugs, to clearly characterize the safety and efficacy of gabapentin and pregabalin in all clinical neuropathic pain syndromes and to further explore the role of these drugs in the rational polypharmacy of neuropathic pain.

ACKNOWLEDGEMENT: This work was supported by Canadian Institutes of Health Research Grant \#69422 and Queen's University Grant \#383-861.

\section{APPENDIX: PUBLICATIONS EXCLUDED FROM REVIEWED RANDOMIZED CONTROLLED TRIALS}

\section{Reason for exclusion: Not a neuropathic pain treatment} trial

- Harding LM, Kristensen JD, Baranowski AP. Differential effects of neuropathicanalgesics on wind-up-like pain and somatosensory function in healthy volunteers. Clin J Pain 2005;21:127-32.

- Gunal AI, Ozalp G, Yoldas TK, Gunal SY, Kirciman E, Celiker H. Gabapentin therapy for pruritus in haemodialysis patients: A randomized, placebo-controlled, double-blind trial. Nephrol Dial Transplant. 2004;19:3137-9.

- Gottrup H, Juhl G, Kristensen AD, et al. Chronic oral gabapentin reduces elements of central sensitization in human experimental hyperalgesia. Anesthesiology 2004;101:1400-8.

- Inghilleri M, Conte A, Frasca V, et al. Antiepileptic drugs and cortical excitability: A study with repetitive transcranial stimulation. Exp Brain Res 2004;154:488-93.

- Dirks J, Fredensborg BB, Christensen D, Fomsgaard JS, Flyger H, Dahl JB. A randomized study of the effects of single-dose gabapentin versus placebo on postoperative pain and morphine consumption after mastectomy. Anesthesiology 2002;97:560-4.

- Chengappa KN, Gershon S, Levine J. The evolving role of topiramate among other mood stabilizers in the management of bipolar disorder. Bipolar Disord 2001;3:215-32.
- Eckhardt K, Ammon S, Hofmann U, Riebe A, Gugeler N, Mikus G. Gabapentin enhances the analgesic effect of morphine in healthy volunteers. Anesth Analg 2000;91:185-91.

- Rovetta G, Baratto L, Monteforte P. Low dose gabapentin for shoulder-hand syndrome induced by phenobarbital: A three-month study. Drugs Exp Clin Res 1999;25:185-91.

- Farrar JT, Young JP, LaMoreaux L, Werth JL, Poole RM. Clinical importance ofchanges in chronic pain intensity measured on an 11-point numerical pain rating scale. Pain 2001;94:149-58

- Jean WH, Wu CC, Mok MS, Sun WZ. Starting dose of gabapentin for patients with post-herpetic neuralgia - a dose-response study. Acta Anaesthesiol Taiwan 2005;43:73-7.

- Medina-Santillan R, Morales-Franco G, Espinoza-Raya J, Granados-Soto V, Reyes-Garcia G. Treatment of diabetic neuropathic pain with gabapentin alone or combined with vitamin $B$ complex. Preliminary results. Proc West Pharmacol Soc 2004; 47:109-12.

- Gomez-Perez FJ, Perez-Monteverde A, Nascimento O, et al. Gabapentin for the treatment of painful diabetic neuropathy: Dosing to achieve optimal clinical response. Br J Diabetes Vasc Dis 2004;4:173-8.

- Aldrete JA, Aldrete VT, Williams SK, Johnson S. Reduction of neuropathic pain in patients with arachnoiditis: Crossover study of gabapentin versus phenytoin. Pain Digest 2000;10:64-7.

- Dallocchio C, Buffa C, Mazzarello P, Chiroli S. Gabapentin vs. amitriptyline in painful diabetic neuropathy: an open-label pilot study. J Pain Symptom Manage 2000;20:280-5.

- Attal N, Brasseur L, Parker F, Chauvin M, Bouhassira D. Effects of gabapentin on the different components of peripheral and central neuropathic pain syndromes: A pilot study. Eur Nerol 1998;40:191-200.

Reason for exclusion: Not a gabapentin/pregabalin trial

- Rowbotham MC, Goli V, Kunz NR, Lei D. Venlafaxine extended release in the treatment of painful diabetic neuropathy: A doubleblind, placebo-controlled study. Pain 2004;110:697-706.

- Meier T, Wasner G, Faust M, et al. Efficacy of lidocaine patch 5\% in the treatment of focal peripheral neuropathic pain syndromes: A randomized, double-blind, placebo-controlled study. Pain 2003;106:151-8.

\section{Reason for exclusion: Not described as a double-blind RCT}

- Yildirim K, Sisecioglu M, Karatay S, et al. The effectiveness of gabapentin in patients with chronic radiculopathy. The Pain Clinic 2003;15:213-8.

- PÈrez HE, Sanchez GF. Gabapentin therapy for diabetic neuropathic pain. Am J Med 2000;108:689.

\section{Reason for exclusion: Review article}

- Backonja MM. Gabapentin monotherapy for the symptomatic treatment of painful neuropathy: A multicenter, double-blind, placebo-controlled trial in patients with diabetes mellitus. Epilepsia 1999;40(Suppl 6):S57-9.

- Beydoun A. Postherpetic neuralgia: Role of gabapentin and other treatment modalities. Epilepsia 1999;40(Suppl 6):S51-6.

- Seidl JJ, Slawson JG. Gabapentin for painful diabetic neuropathy. J Fam Pract 1999;48:173-4.

\section{Reason for exclusion: Abstract}

- Toelle T, Versavel M, Glessner C, Trostmann U. A novel treatment for diabetic peripheral neuropathy: Pregabalin dose and pain relief. American Society of Anesthesiologists' Annual Meeting Abstracts. 2004:A-967.

- Nocivin D. Gabapentin and amitriptyline in the treatment of postherpetic neuralgia. J Eur Acad Dermatol Venereol 2003;17(Suppl 3):345.

- Backonja MM, Mutisya E. Dose response to gabapentin across five multicenter trials for neuropathic pain. Ann Neurol 2002;(Suppl 1):S81 


\section{REFERENCES}

1. Bryans JS, Wustrow DJ. 3-substituted GABA analogs with central nervous system activity: A review. Med Res Rev 1999;19:149-77.

2. Chadwick D. Gabapentin. Lancet 1994;343:89-91.

3. Mellick LB, Mellick GA. Successful treatment of reflex sympathetic dystrophy with gabapentin. Am J Emerg Med 1995;13:96.

4. Segal AZ, Rordorf G. Gabapentin as a novel treatment for postherpetic neuralgia. Neurology 1996;46:1175-6.

5. Rosner H, Rubin L, Kestenbaum A. Gabapentin adjunctive therapy in neuropathic pain states. Clin J Pain 1996;12:56-8.

6. Xiao WH, Bennett GJ. Gabapentin has an antinociceptive effect mediated via a spinal site action in a rat model of painful peripheral neuropathy. Analgesia 1996;2:267-73.

7. Hwang JH, Yaksh TL. Effect of subarachnoid gabapentin on tactileevoked allodynia in a surgically induced neuropathic pain model in the rat. Reg Anesth 1997;22:249-56.

8. Backonja M, Beydoun A, Edwards KR, et al. Gabapentin for the symptomatic treatment of painful neuropathy in patients with diabetes mellitus: A randomized controlled trial. JAMA 1998;280:1831-6.

9. Rowbotham M, Harden N, Stacey B, Bernstein P, Magnus-Miller L. Gabapentin for the treatment of postherpetic neuralgia: A randomized controlled trial. JAMA 1998;280:1837-42.

10. Andruszkiewicz RS, Silverman RB. A convenient synthesis of 3 alkyl-4-aminobutanoic acids. Synthesis 1989:953-955.

11. Hansson PT. Neuropathic pain: Definition, epidemiology, classification, and diagnostic work-up. In: Justins DM, ed. Pain 2005 - An Updated Review Refresher Course Syllabus. Seattle: IASP Press, 2005:91-6.

12. Bennett GJ. Experimental neuropathic pain in animals: Models and mechanisms. In: Justins DM, ed. Pain 2005 - An Updated Review Refresher Course Syllabus. Seattle: IASP Press, 2005:97-106.

13. Fox A, Gentry C, Patel S, Kesingland A, Bevan S. Comparative activity of the anti-convulsants oxcarbazepine, carbamazepine, lamotrigine and gabapentin in a model of neuropathic pain in the rat and guinea-pig. Pain 2003;105:355-62.

14. Erichsen HK, Blackburn-Munro G. Pharmacological characterisation of the spared nerve injury model of neuropathic pain. Pain 2002;98:151-61.

15. LaBuda CJ, Fuchs PN. Morphine and gabapentin decrease mechanical hyperalgesia and escape/avoidance behavior in a rat model of neuropathic pain. Neurosci Lett 2000;290:137-40.

16. Kayser V, Christensen D. Antinociceptive effect of systemic gabapentin in mononeuropathic rats, depends on stimulus characteristics and level of test integration. Pain 2000;88:53-60.

17. Hunter JC, Gogas KR, Hedley LR, et al. The effect of novel antiepileptic drugs in rat experimental models of acute and chronic pain. Eur J Pharmacol 1997;324:153-60.

18. Abdi S, Lee DH, Chung JM. The anti-allodynic effects of amitriptyline, gabapentin, and lidocaine in a rat model of neuropathic pain. Anesth Analg 1998;87:1360-6.

19. De Vry J, Kuhl E, Franken-Kunkel P, Eckel G. Pharmacological characterization of the chronic constriction injury model of neuropathic pain. Eur J Pharmacol 2004;491:137-48.

20. Pan HL, Eisenach JC, Chen SR. Gabapentin suppresses ectopic nerve discharges and reverses allodynia in neuropathic rats. J Pharmacol Exp Ther 1999;288:1026-30.

21. Urban MO, Ren K, Park KT, et al. Comparison of the antinociceptive profiles of gabapentin and 3-methylgabapentin in rat models of acute and persistent pain: Implications for mechanism of action. J Pharmacol Exp Ther 2005;313:1209-16.

22. Xiao WH, Siau C, Bennett GJ. Effect of gabapentin in chemotherapy-evoked neuropathic pain in the rat. Soc Neurosci Abstr 2004:982.985.

23. Hao JX, Xu XJ, Urban L, Wiesenfeld-Hallin Z. Repeated administration of systemic gabapentin alleviates allodynia-like behaviors in spinally injured rats. Neurosci Lett 2000;280:211-4.

24. Field MJ, McCleary S, Hughes J, Singh L. Gabapentin and pregabalin, but not morphine and amitriptyline, block both static and dynamic components of mechanical allodynia induced by streptozocin in the rat. Pain 1999;80:391-8.

25. Chen SR, Pan HL. Effect of systemic and intrathecal gabapentin on allodynia in a new rat model of postherpetic neuralgia. Brain Res 2005;1042:108-13.

26. Takasaki I, Andoh T, Nojima H, Shiraki K, Kuraishi Y. Gabapentin antinociception in mice with acute herpetic pain induced by herpes
27. Field MJ, Bramwell S, Hughes J, Singh L. Detection of static and dynamic components of mechanical allodynia in rat models of neuropathic pain: Are they signalled by distinct primary sensory neurones? Pain 1999;83:303-11.

28. Chen SR, Xu Z, Pan HL. Stereospecific effect of pregabalin on ectopic afferent discharges and neuropathic pain induced by sciatic nerve ligation in rats. Anesthesiology 2001;95:1473-9.

29. Wallin J, Cui JG, Yakhnitsa V, Schechtmann G, Meyerson BA, Linderoth B: Gabapentin and pregabalin suppress tactile allodynia and potentiate spinal cord stimulation in a model of neuropathy. Eur J Pain 2002;6:261-72.

30. Nozaki-Taguchi N, Chaplan SR, Higuera ES, Ajakwe RC, Yaksh TL. Vincristine-induced allodynia in the rat. Pain 2001;93:69-76.

31. Suman-Chauhan N, Webdale L, Hill DR, Woodruff GN. Characterisation of $[3 \mathrm{H}]$ gabapentin binding to a novel site in rat brain: Homogenate binding studies. Eur J Pharmacol 1993;244:293-301.

32. Lanneau C, Green A, Hirst WD, et al. Gabapentin is not a GABAB receptor agonist. Neuropharmacology 2001;41:965-75.

33. Taylor CP. The biology and pharmacology of calcium channel alpha2-delta proteins. Pfizer Satellite Symposium to the 2003 Society for Neuroscience Meeting. Sheraton New Orleans Hotel, New Orleans, LA November 10, 2003. CNS Drug Rev 2004;10:183-88.

34. Ben-Menachem E: Pregabalin pharmacology and its relevance to clinical practice. Epilepsia 2004;45(Suppl 6):13-8.

35. Patel S, Naeem S, Kesingland A, et al. The effects of GABA(B) agonists and gabapentin on mechanical hyperalgesia in models of neuropathic and inflammatory pain in the rat. Pain 2001;90:217-26.

36. Cheng JK, Chiou LC. Mechanisms of the antinociceptive action of gabapentin. J Pharmacol Sci 2006; [Epub ahead of print].

37. Gee NS, Brown JP, Dissanayake VU, Offord J, Thurlow R, Woodruff GN. The novel anticonvulsant drug, gabapentin (Neurontin), binds to the alpha2delta subunit of a calcium channel. J Biol Chem 1996;271:5768-76.

38. Ertel EA, Campbell KP, Harpold MM, et al. Nomenclature of voltage-gated calcium channels. Neuron 2000;25:533-5.

39. Yusaf SP, Goodman J, Pinnock RD, Dixon AK, Lee K. Expression of voltage-gated calcium channel subunits in rat dorsal root ganglion neurons. Neurosci Lett 2001;311:137-41.

40. Marais E, Klugbauer N, Hofmann F. Calcium channel alpha(2)delta subunits-structure and Gabapentin binding. Mol Pharmacol 2001;59:1243-8.

41. Qin N, Yagel S, Momplaisir ML, Codd EE, D'Andrea MR. Molecular cloning and characterization of the human voltage-gated calcium channel alpha(2)delta-4 subunit. Mol Pharmacol 2002;62:485-96.

42. Luo ZD, Chaplan SR, Higuera ES, et al. Upregulation of dorsal root ganglion (alpha)2(delta) calcium channel subunit and its correlation with allodynia in spinal nerve-injured rats. J Neurosci 2001;21:1868-75.

43. Newton RA, Bingham S, Case PC, Sanger GJ, Lawson SN. Dorsal root ganglion neurons show increased expression of the calcium channel alpha2delta-1 subunit following partial sciatic nerve injury. Brain Res Mol Brain Res 2001;95:1-8.

44. Li CY, Song YH, Higuera ES, Luo ZD. Spinal dorsal horn calcium channel alpha2delta-1 subunit upregulation contributes to peripheral nerve injury-induced tactile allodynia. J Neurosci 2004;24:8494-9.

45. Luo ZD, Calcutt NA, Higuera ES, et al. Injury type-specific calcium channel alpha 2 delta-1 subunit up-regulation in rat neuropathic pain models correlates with antiallodynic effects of gabapentin. J Pharmacol Exp Ther 2002;303:1199-205.

46. Coderre TJ, Kumar N, Lefebvre CD, Yu JS. Evidence that gabapentin reduces neuropathic pain by inhibiting the spinal release of glutamate. J Neurochem 2005;94:1131-9.

47. Ingram RA, Jones MG, Malcangio M, McMahon SB. Mechanisms of gabapentin action in neuropathic rats. In Abstracts: 11th World Congress on Pain. IASP Press, 2005:1567

48. Yang RH, Xing JL, Duan JH, Hu SJ. Effects of gabapentin on spontaneous discharges and subthreshold membrane potential oscillation of type A neurons in injured DRG. Pain 2005;116:187-93.

49. Chapman V, Suzuki R, Chamarette HL, Rygh LJ, Dickenson AH. Effects of systemic carbamazepine and gabapentin on spinal neuronal responses in spinal nerve ligated rats. Pain 1998;75:261-72.

50. Patel MK, Gonzalez MI, Bramwell S, Pinnock RD, Lee K. 
Gabapentin inhibits excitatory synaptic transmission in the hyperalgesic spinal cord. Br J Pharmacol 2000;130:1731-4.

51. Tanabe M, Takasu K, Kasuya N, Shimizu S, Honda M, Ono H. Role of descending noradrenergic system and spinal alpha2-adrenergic receptors in the effects of gabapentin on thermal and mechanical nociception after partial nerve injury in the mouse. Br J Pharmacol 2005;144:703-14

52. Suzuki R, Rahman W, Rygh LJ, Webber M, Hunt SP, Dickenson AH. Spinal-supraspinal serotonergic circuits regulating neuropathic pain and its treatment with gabapentin. Pain 2005;117:292-303.

53. Mellegers MA, Furlan AD, Mailis A. Gabapentin for neuropathic pain: Systematic review of controlled and uncontrolled literature. Clin J Pain 2001;17:284-95.

54. Laird MA, Gidal BE. Use of gabapentin in the treatment of neuropathic pain. Ann Pharmacother 2000;34:802-7.

55. Jadad AR, Moore RA, Carroll D, et al. Assessing the quality of reports of randomized clinical trials: Is blinding necessary? Control Clin Trials 1996;17:1-12

56. Sinnreich M, Taylor BV, Dyck PJ. Diabetic neuropathies. Classification, clinical features, and pathophysiological basis. Neurologist 2005;11:63-79.

57. Schmader KE. Epidemiology and impact on quality of life of postherpetic neuralgia and painful diabetic neuropathy. Clin J Pain 2002;18:350-4

58. Vinik AI. Diabetic neuropathy: pathogenesis and therapy. Am J Med 1999; 107:17S-26S

59. Dyck PJ, Lambert EH, O'Brien PC. Pain in peripheral neuropathy related to rate and kind of fiber degeneration. Neurology $1976 ; 26: 466-71$.

60. Attal N, Bouhassira D. Mechanisms of pain in peripheral neuropathy. Acta Neurol Scand Suppl 1999;173:12-24; 48-52.

61. Baron R, Maier C. Painful neuropathy: C-nociceptor activity may not be necessary to maintain central mechanisms accounting for dynamic mechanical allodynia. Clin J Pain 1995;11:63-9.

62. Morello CM, Leckband SG, Stoner CP, Moorhouse DF, Sahagian GA. Randomized double-blind study comparing the efficacy of gabapentin with amitriptyline on diabetic peripheral neuropathy pain. Arch Intern Med 1999;159:1931-7.

63. Gilron I, Bailey JM, Tu D, Holden RR, Weaver DF, Houlden RL. Morphine, gabapentin, or their combination for neuropathic pain. N Engl J Med 2005;352:1324-34.

64. Freynhagen R, Strojek K, Griesing T, Whalen E, Balkenohl M. Efficacy of pregabalin in neuropathic pain evaluated in a 12 -week, randomised, double-blind, multicentre, placebo-controlled trial of flexible- and fixed-dose regimens. Pain 2005;115:254-63.

65. Simpson DA. Gabapentin and venlafaxine for the treatment of painful diabetic neuropathy. J Clin Neuromusc Dis 2001;3:53-62.

66. Gorson KC, Schott C, Herman R, Ropper AH, Rand WM. Gabapentin in the treatment of painful diabetic neuropathy: A placebo controlled, double blind, crossover trial. J Neurol Neurosurg Psychiatry 1999;66:251-2.

67. Lesser H, Sharma U, LaMoreaux L, Poole RM. Pregabalin relieves symptoms of painful diabetic neuropathy: A randomized controlled trial. Neurology 2004;63:2104-10.

68. Rosenstock J, Tuchman M, LaMoreaux L, Sharma U. Pregabalin for the treatment of painful diabetic peripheral neuropathy: A doubleblind, placebo-controlled trial. Pain 2004;110:628-38.

69. Richter RW, Portenoy R, Sharma U, Lamoreaux L, Bockbrader H, Knapp LE. Relief of painful diabetic peripheral neuropathy with pregabalin: A randomized, placebo-controlled trial. J Pain 2005;6:253-60.

70. Toelle T, Versavel M, Glessner C, Trostmann U. A novel treatment for diabetic peripheral neuropathy: Pregabalin dose and pain relief. In: American Society of Anesthesiologists' Annual Meeting 2004: A-967. (Abst)

71. Oaklander AL. The pathology of shingles: Head and Campbell's 1900 monograph. Arch Neurol 1999;56:1292-4.

72. Watson CP, Deck JH, Morshead C, Van der Kooy D, Evans RJ. Postherpetic neuralgia: Further post-mortem studies of cases with and without pain. Pain 1991;44:105-17.

73. Fields HL, Rowbotham M, Baron R. Postherpetic neuralgia: Irritable nociceptors and deafferentation. Neurobiol Dis 1998;5:209-27.

74. Rice AS, Maton S. Gabapentin in postherpetic neuralgia: A randomised, double blind, placebo controlled study. Pain 2001;94:215-24.
75. Dworkin RH, Corbin AE, Young JP Jr, et al. Pregabalin for the treatment of postherpetic neuralgia: A randomized, placebocontrolled trial. Neurology 2003;60:1274-83.

76. Sabatowski R, Galvez R, Cherry DA, et al. Pregabalin reduces pain and improves sleep and mood disturbances in patients with postherpetic neuralgia: Results of a randomised, placebo-controlled clinical trial. Pain 2004;109:26-35.

77. van Seventer R, Feister HA, Young JP Jr, Stoker M, Versavel M, Rigaudy L. Efficacy and tolerability of twice-daily pregabalin for treating pain and related sleep interference in postherpetic neuralgia: A 13-week, randomized trial. Curr Med Res Opin 2006;22:375-84.

78. Finnerup NB, Otto M, McQuay HJ, Jensen TS, Sindrup SH. Algorithm for neuropathic pain treatment: An evidence based proposal. Pain 2005;118:289-305.

79. Gilron I, Watson CP, Cahill CM, Moulin DE. Neuropathic pain: A practical guide for the clinician. CMAJ 2006. (In press)

80. Tai Q, Kirshblum S, Chen B, Millis S, Johnston M, DeLisa JA. Gabapentin in the treatment of neuropathic pain after spinal cord injury: A prospective, randomized, double-blind, crossover trial. J Spinal Cord Med 2002;25:100-5.

81. Bone M, Critchley P, Buggy DJ. Gabapentin in postamputation phantom limb pain: A randomized, double-blind, placebo-controlled, cross-over study. Reg Anesth Pain Med 2002;27:481-6.

82. Serpell MG. Gabapentin in neuropathic pain syndromes: A randomised, double-blind, placebo-controlled trial. Pain 2002;99:557-66.

83. Pandey CK, Bose N, Garg G, et al. Gabapentin for the treatment of pain in guillain-barre syndrome: A double-blinded, placebocontrolled, crossover study. Anesth Analg 2002;95:1719-23.

84. Levendoglu F, Ogun CO, Ozerbil O, Ogun TC, Ugurlu H. Gabapentin is a first line drug for the treatment of neuropathic pain in spinal cord injury. Spine 2004;29:743-51.

85. Caraceni A, Zecca E, Bonezzi C, et al. Gabapentin for neuropathic cancer pain: A randomized controlled trial from the Gabapentin Cancer Pain Study Group. J Clin Oncol 2004;22:2909-17.

86. van de Vusse AC, Stomp-van den Berg SG, Kessels AH, Weber WE. Randomised controlled trial of gabapentin in complex regional pain syndrome type 1 [ISRCTN84121379]. BMC Neurol 2004;4:13.

87. Hahn K, Arendt G, Braun JS, et al. A placebo-controlled trial of gabapentin for painful HIV-associated sensory neuropathies. J Neurol 2004;251:1260-6.

88. Fischer JH, Barr AN, Rogers SL, Fischer PA, Trudeau VL. Lack of serious toxicity following gabapentin overdose. Neurology 1994;44:982-3.

89. Rosebush PI, MacQueen GM, Mazurek MF. Catatonia following gabapentin withdrawal. J Clin Psychopharmacol 1999;19:188-9.

90. Norton JW. Gabapentin withdrawal syndrome. Clin Neuropharmacol 2001;24:245-6.

91. Barrueto F Jr, Green J, Howland MA, Hoffman RS, Nelson LS. Gabapentin withdrawal presenting as status epilepticus. J Toxicol Clin Toxicol 2002;40:925-8

92. Drabkin R, Calhoun L. Anorgasmia and withdrawal syndrome in a woman taking gabapentin. Can J Psychiatry 2003;48:125-6.

93. Tran KT, Hranicky D, Lark T, Jacob N. Gabapentin withdrawal syndrome in the presence of a taper. Bipolar Disord 2005; 7:302-4.

94. Reeves AL, So EL, Sharbrough FW, Krahn LE. Movement disorders associated with the use of gabapentin. Epilepsia 1996;37:988-90.

95. Jacob PC, Chand RP, Omeima el-S. Asterixis induced by gabapentin. Clin Neuropharmacol 2000;23:53.

96. Asconape J, Diedrich A, DellaBadia J. Myoclonus associated with the use of gabapentin. Epilepsia 2000;41:479-81.

97. Pina MA, Modrego PJ. Dystonia induced by gabapentin. Ann Pharmacother 2005;39:380-2.

98. Babiy M, Stubblefield MD, Herklotz M, Hand M. Asterixis related to gabapentin as a cause of falls. Am J Phys Med Rehabil 2005;84:136-40.

99. Boneva N, Brenner T, Argov Z: Gabapentin may be hazardous in myasthenia gravis. Muscle Nerve 2000;23:1204-8

100. Scheschonka A, Beuche W. Treatment of post-herpetic pain in myasthenia gravis: Exacerbation of weakness due to gabapentin. Pain 2003;104:423-4.

101. Childers MK, Holland D. Psychomotor agitation following gabapentin use in brain injury. Brain Inj 1997;11:537-40.

102. Gallay BJ, de Mattos AM, Norman DJ. Reversible acute renal allograft dysfunction due to gabapentin. Transplantation 2000;70:208-9 
103. Berger JJ. Amenorrhea in a patient after treatment with gabapentin for complex regional pain syndrome type II. Clin J Pain 2004;20:192-4.

104. Almahrezi A, Fitzcharles MA. Dose-dependent severe arthralgia induced by gabapentin. J Rheumatol 2004;31:1228.

105. Wolf SM, Shinnar S, Kang H, Gil KB, Moshe SL. Gabapentin toxicity in children manifesting as behavioral changes. Epilepsia 1995;36:1203-5.

106. Zylicz Z. Painful gynecomastia: An unusual toxicity of gabapentin? J Pain Symptom Manage 2000;20:2-3.

107. Poon DY, Law NM. A case of cutaneous leukocytoclastic vasculitis associated with gabapentin. Singapore Med J 2003;44:42-4.

108. Derbyshire E, Martin D. Neutropenia occurring after starting gabapentin for neuropathic pain. Clin Oncol (R Coll Radiol) 2004;16:575-6.

109. Morris GL. Gabapentin. Epilepsia 1999;40(Suppl 5):S63-70.

110. Parsons B, Tive L, Huang S. Gabapentin: A pooled analysis of adverse events from three clinical trials in patients with postherpetic neuralgia. Am J Geriatr Pharmacother 2004;2:157-62.

111. Shneker BF, McAuley JW. Pregabalin: A new neuromodulator with broad therapeutic indications. Ann Pharmacother 2005;39:2029-37.

112. Huppertz HJ, Feuerstein TJ, Schulze-Bonhage A. Myoclonus in epilepsy patients with anticonvulsive add-on therapy with pregabalin. Epilepsia 2001;42:790-2.

113. Heckmann JG, Ulrich K, Dutsch M, Neundorfer B. Pregabalin associated asterixis. Am J Phys Med Rehabil 2005;84:724.

114. Oaklander AL, Buchbinder BR: Pregabalin-withdrawal encephalopathy and splenial edema: A link to high-altitude illness? Ann Neurol 2005;58:309-12.

115. Dworkin RH, Backonja M, Rowbotham MC, et al. Advances in neuropathic pain: Diagnosis, mechanisms, and treatment recommendations. Arch Neurol 2003;60:1524-34.

116. Chen H, Lamer TJ, Rho RH, et al. Contemporary management of neuropathic pain for the primary care physician. Mayo Clin Proc 2004;79:1533-45.

117. McLean MJ. Clinical pharmacokinetics of gabapentin. Neurology 1994;44:S17-22; S31-12.
118. McLean MJ, Gidal BE. Gabapentin dosing in the treatment of epilepsy. Clin Ther 2003;25:1382-406.

119. Cho HS, Kim MH, Choi DH, Lee JI, Gwak MS, Hahm TS. The effect of intrathecal gabapentin on mechanical and thermal hyperalgesia in neuropathic rats induced by spinal nerve ligation. J Korean Med Sci 2002;17:225-9.

120. Christensen D, Gautron M, Guilbaud G, Kayser V. Effect of gabapentin and lamotrigine on mechanical allodynia-like behaviour in a rat model of trigeminal neuropathic pain. Pain 2001;93:147-53.

121. Hofmann HA, De Vry J, Siegling A, Spreyer P, Denzer D. Pharmacological sensitivity and gene expression analysis of the tibial nerve injury model of neuropathic pain. Eur J Pharmacol 2003;470:17-25.

122. Rodrigues-Filho R, Campos MM, Ferreira J, Santos AR, Bertelli JA, Calixto JB. Pharmacological characterisation of the rat brachial plexus avulsion model of neuropathic pain. Brain Res 2004;1018:159-70.

123. Back SK, Won SY, Hong SK, Na HS. Gabapentin relieves mechanical, warm and cold allodynia in a rat model of peripheral neuropathy. Neurosci Lett 2004;368:341-4.

124. Hulsebosch CE, Xu GY, Perez-Polo JR, Westlund KN, Taylor CP, McAdoo DJ. Rodent model of chronic central pain after spinal cord contusion injury and effects of gabapentin. J Neurotrauma 2000;17:1205-17.

125. Miki S, Yoshinaga N, Iwamoto T, Yasuda T, Sato S. Antinociceptive effect of the novel compound OT-7100 in a diabetic neuropathy model. Eur J Pharmacol 2001;430:229-34

126. Takasaki I, Sasaki A, Andoh T, Nojima H, Shiraki K, Kuraishi Y. Effects of analgesics on delayed postherpetic pain in mice. Anesthesiology 2002;96:1168-74.

127. Lynch JJ III, Wade CL, Zhong CM, Mikusa JP, Honore P. Attenuation of mechanical allodynia by clinically utilized drugs in a rat chemotherapy-induced neuropathic pain model. Pain 2004;110:56-63.

128. Neurontin Product Monograph. Compendium of Pharmaceuticals and Specialties 2006, Canadian Pharmacists Association.

129. Lyrica Product Monograph. Compendium of Pharmaceuticals and Specialties 2006, Canadian Pharmacists Association. 


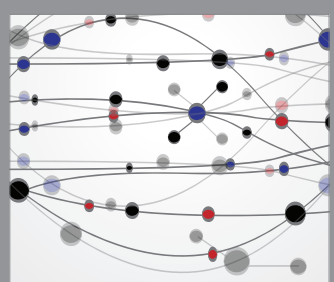

The Scientific World Journal
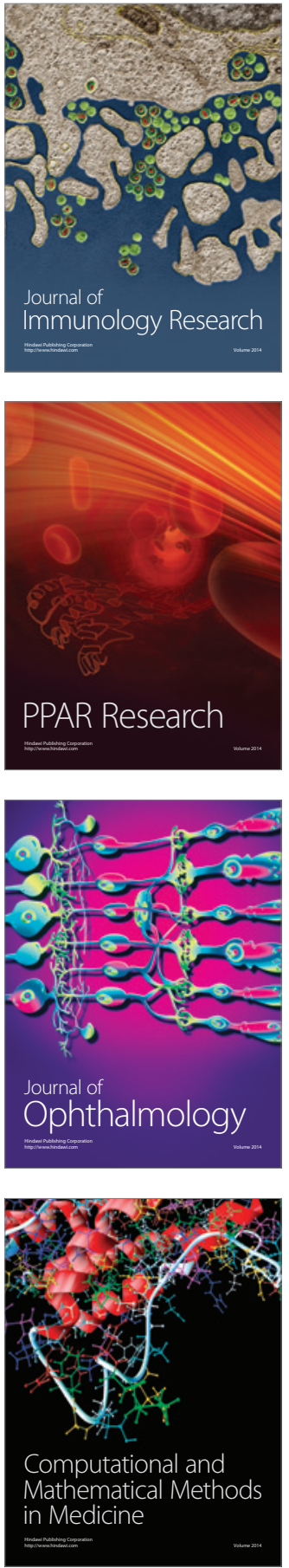

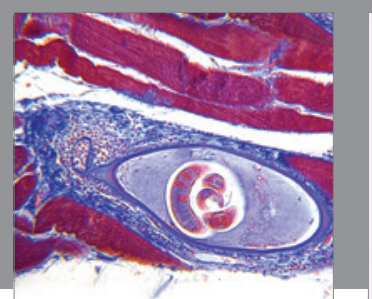

Gastroenterology Research and Practice

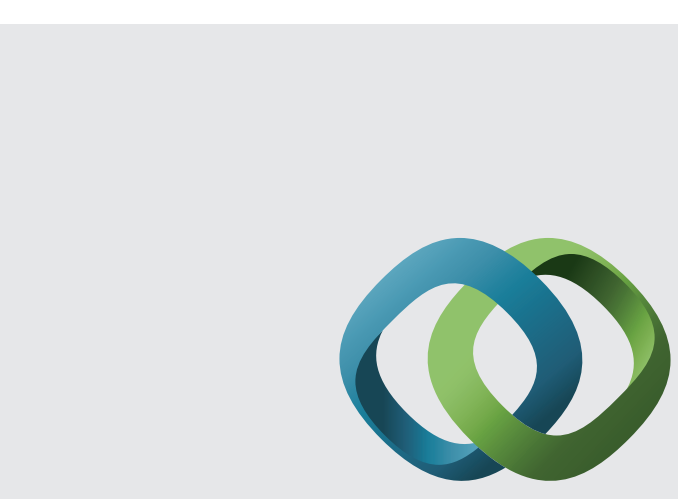

\section{Hindawi}

Submit your manuscripts at

http://www.hindawi.com
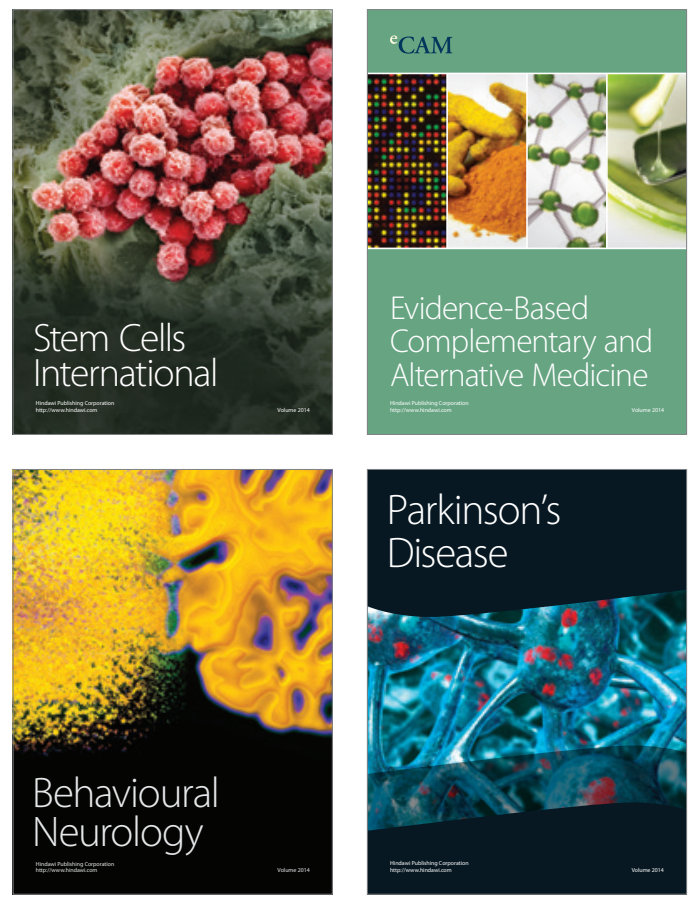
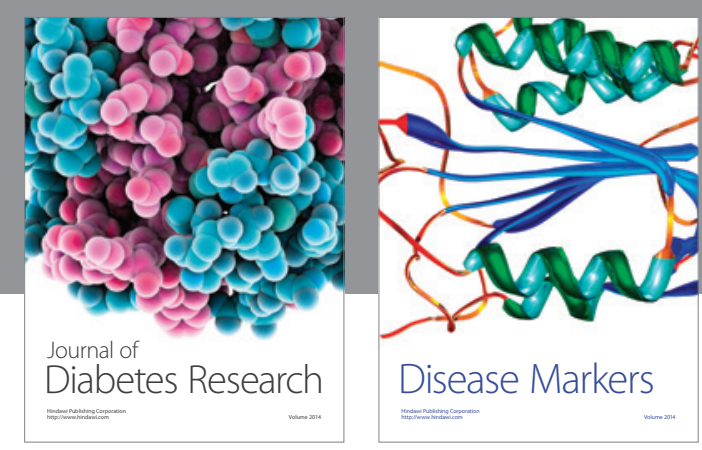

Disease Markers
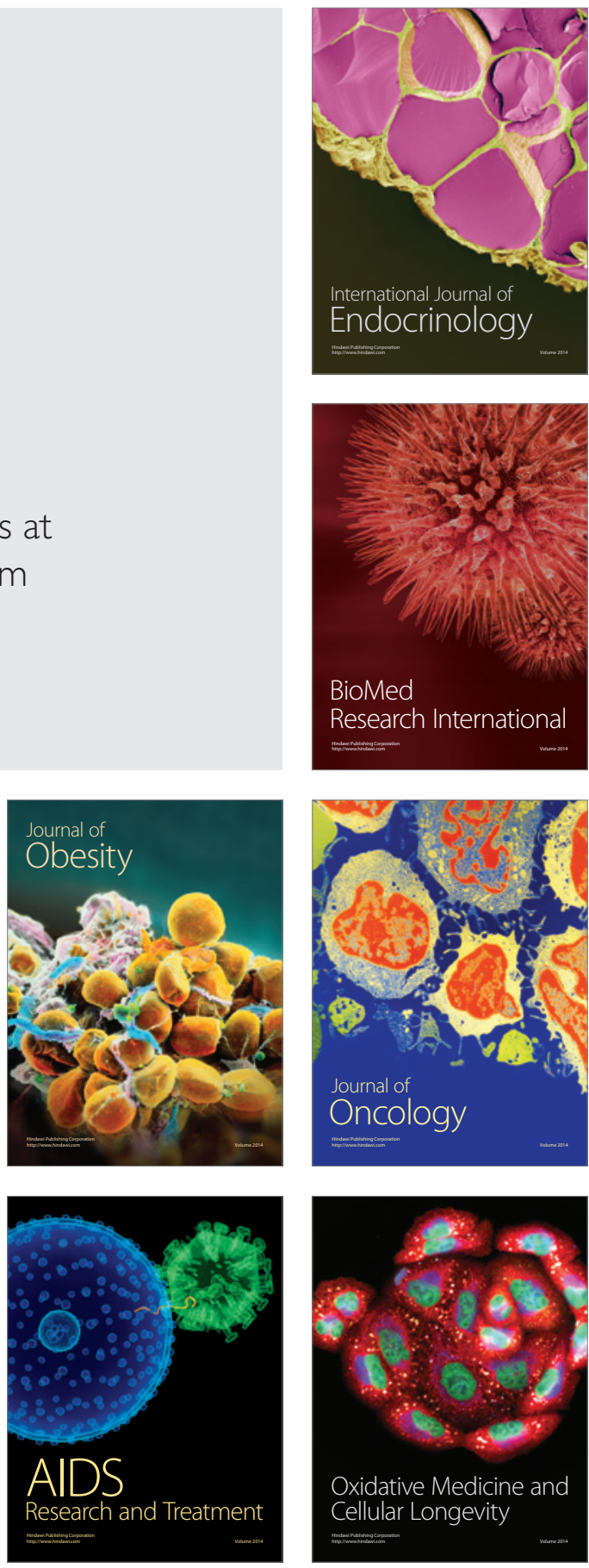